Western University

Scholarship@Western

Chemistry Publications

Chemistry Department

Summer 6-26-2015

\title{
Synthesis and Characterization of Conjugated/ Cross-Conjugated Benzene-Bridged Boron Difluoride Formazanate Dimers
}

Stephanie M. Barbon

Jacquelyn T. Price

Umesh Yogarajah

Joe Gilroy

jgilroy5@uwo.ca

Follow this and additional works at: https://ir.lib.uwo.ca/chempub

Part of the Chemistry Commons

Citation of this paper:

Barbon, Stephanie M.; Price, Jacquelyn T.; Yogarajah, Umesh; and Gilroy, Joe, "Synthesis and Characterization of Conjugated/CrossConjugated Benzene-Bridged Boron Difluoride Formazanate Dimers" (2015). Chemistry Publications. 67.

https://ir.lib.uwo.ca/chempub/67 


\section{Synthesis and Characterization of Conjugated/Cross-}

\section{Conjugated Benzene-Bridged Boron Difluoride}

\section{Formazanate Dimers $\uparrow$}

Stephanie M. Barbon, Jacquelyn T. Price, Umesh Yogarajah and Joe B. Gilroy*

Department of Chemistry and the Centre for Advanced Materials and Biomaterials Research (CAMBR), The University of Western Ontario, 1151 Richmond St. N., London, Ontario, Canada, N6A 5B7. Tel: +1-519-661-2111 ext. 81561, E-mail: joe.gilroy@uwo.ca.

$†$ Electronic supplementary information (ESI) available. See DOI:10.1039/\#\#\#\#\#\#

\section{TOC Entry:}
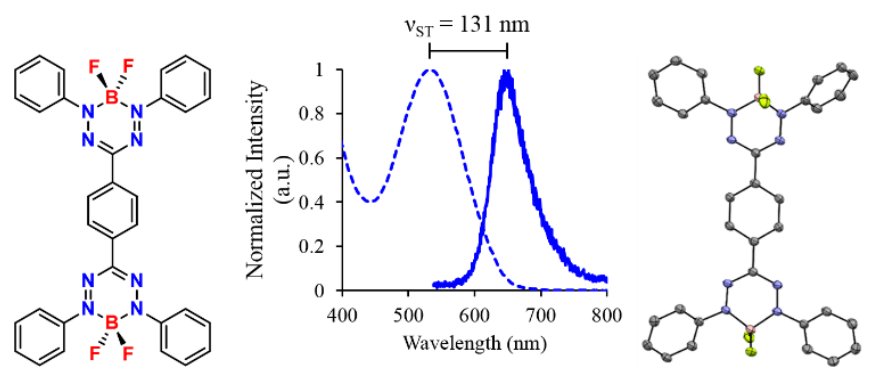

A study designed to probe the effect of electronic conjugation and cross-conjugation on the optical and electrochemical properties of benzene-bridged boron difluoride formazanate dimers is presented. 


\begin{abstract}
One of the most common strategies for the production of molecular materials with optical properties in the far-red/near-IR regions of the electromagnetic spectrum is their incorporation into dimeric architectures. In this paper, we describe the synthesis and characterization $\left({ }^{1} \mathrm{H},{ }^{11} \mathrm{~B}\right.$, ${ }^{13} \mathrm{C}$ and ${ }^{19} \mathrm{~F}$ NMR spectroscopy, IR and UV-Vis absorption and emission spectroscopy, mass spectrometry and X-ray crystallography) of the first examples of boron difluoride $\left(\mathrm{BF}_{2}\right)$ formazanate dimers. Specifically, the properties of meta- and para-substituted benzene-bridged dimers $\boldsymbol{p - 1 0}$ and $\boldsymbol{m - 1 0}$ were compared to closely related boron difluoride triphenyl formazanate complex 11 in order to assess the effect of electronic conjugation and cross conjugation on their light absorption/emission and electrochemical properties. While the properties of crossconjugated dimer $\boldsymbol{m - 1 0}$ did not differ significantly from those of monomer $\mathbf{1 1}$, conjugated dimer p-10 exhibited red-shifted absorption and emission maxima and was easier to reduce electrochemically to its bis radical anion and bis dianion form compared to monomer 11. Both dimers are weakly emissive in the far-red/near-IR and exhibited large Stokes shifts (> $110 \mathrm{~nm}$, $3318 \mathrm{~cm}^{-1}$ ). Unlike a closely related para-substituted benzene-bridged boron dipyrromethene (BODIPY) dimer, the emission quantum yields measured for the $\mathrm{BF}_{2}$ formazanate dimers exceeded those observed for monomeric analogues.
\end{abstract}

\title{
Introduction
}

Boron difluoride $\left(\mathrm{BF}_{2}\right)$ complexes (or dyes) derived from chelating $N$-donor ligands ${ }^{1,2}$ have received significant attention over the past two decades as a result of their structurally tunable electrochemical and light absorbing/emitting properties. However, the vast majority of these dyes exhibit small Stokes shifts $\left(\cup_{\mathrm{ST}}\right)$ and their maximum absorption/emission occur in the visible region of the electromagnetic spectrum. 
For many applications, including biological imaging, ${ }^{3,4}$ light emitting diodes ${ }^{5}$ and high performance organic solar cells ${ }^{6}$ materials with maximum absorption/emission wavelengths in the far-red/near-IR regions of the electromagnetic spectrum are required. One of the most common strategies for the production of $\mathrm{BF}_{2}$ dyes exhibiting low-energy absorption and emission maxima involves combining two or more $\mathrm{BF}_{2}$ dye moieties into a single molecule. ${ }^{7}$ This approach has been applied to perhaps the most widely recognized of the $\mathrm{BF}_{2}$ complexes boron dipyrromethenes (BODIPYs). ${ }^{\text {la-c }}$ The unsubstituted BODIPY core $\mathbf{1}$ has excellent photophysical properties, including sharp and intense absorption [wavelength of maximum absorption $\left(\lambda_{\max }\right)=500 \mathrm{~nm}$ in THF] and emission [wavelength of maximum emission $\left(\lambda_{\mathrm{em}}\right)=$ $516 \mathrm{~nm}$ in THF] bands and high emission quantum yield $\left(\Phi_{\mathrm{f}}=0.77\right) .{ }^{8}$ Structural modification to red-shift the absorption and emission features of these molecule often prove to be challenging. Ziegler and co-workers have directly fused two BODIPY-like units together to form novel bis(difluoroboron)1,2-bis((1H-pyrrol-2-yl)methylene)hydrazines (BOPHYs) $2,{ }^{9}$ which have been subsequently studied as functional materials. ${ }^{10}$ BOPHY 2 has an impressive emission quantum yield of 0.95 in $\mathrm{CH}_{2} \mathrm{Cl}_{2}$, although, both the emission and absorption were blue-shifted with respect to 1 . By fusing together two BODIPY units with benzene rings and effectively extending $\pi$ conjugation, for example, in dimers $\mathbf{3}-\mathbf{5}, \lambda_{\mathrm{em}}$ red-shifts significantly to $940 \mathrm{~nm} \mathrm{(3)},{ }^{11} 712 \mathrm{~nm}$ (4) ${ }^{12}$ and $868 \mathrm{~nm}(\mathbf{5}) \cdot{ }^{13}$ With the exception of compound 4, the emission quantum yields drop off significantly, to less than 0.05 . 
<smiles></smiles>

$\lambda_{\text {max }}=500 \mathrm{~nm}$

$\lambda_{\text {em }}=516 \mathrm{~nm}$

$\Phi_{\mathrm{f}}=0.77$

$\varepsilon=80000$

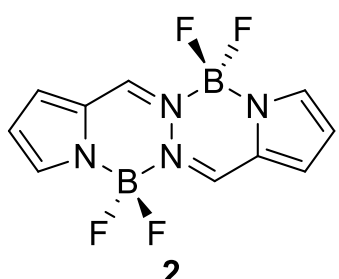

$\lambda_{\text {max }}=442 \mathrm{~nm}$

$\lambda_{\mathrm{em}}=493 \mathrm{~nm}$

$\Phi_{\mathrm{f}}=0.95$

$\varepsilon=38600$

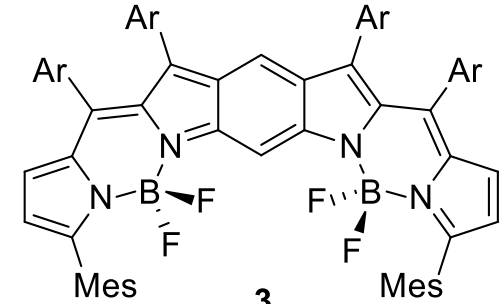

$\lambda_{\text {max }}=629 \mathrm{~nm}$

$\lambda_{\text {em }}=940 \mathrm{~nm}$

$\Phi_{\mathrm{f}}<0.01$

$\varepsilon=100000$

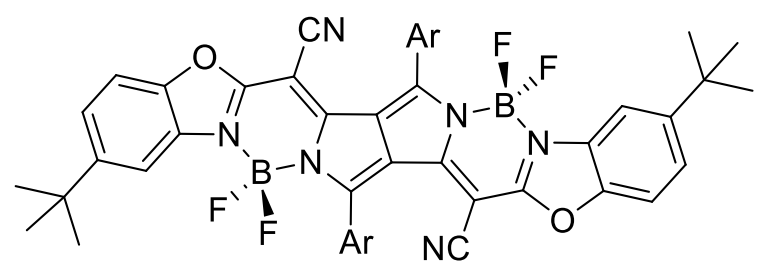

4

$\lambda_{\max }=690 \mathrm{~nm}$

$\lambda_{\text {em }}=712 \mathrm{~nm}$

$\Phi_{\mathrm{f}}=0.57$

$\varepsilon=135000$

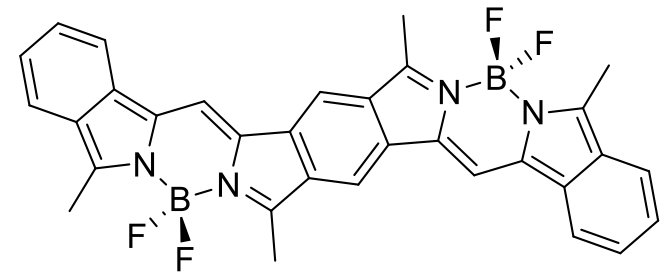

$$
\begin{gathered}
\mathbf{5} \\
\lambda_{\max }=848 \mathrm{~nm} \\
\lambda_{\mathrm{em}}=868 \mathrm{~nm} \\
\Phi_{\mathrm{f}}=0.04 \\
\varepsilon=55600
\end{gathered}
$$

BODIPY units have also been linked via para-benzene spacers, e.g., 6, whereby the wavelength of maximum emission was red-shifted relative to model compound 7 and emission quantum yields decreased from 0.29 for 7 to 0.05 for $\mathbf{6}^{14}$

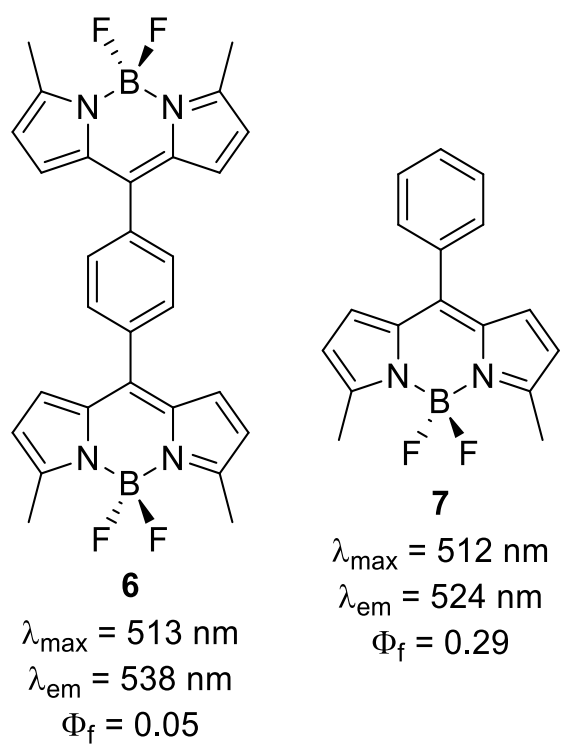


Building on recent advances surrounding the coordination chemistry of formazanate ligands ${ }^{15}$ we have explored the structurally tunable properties of $\mathrm{BF}_{2}$ formazanate complexes ${ }^{16}$ and demonstrated their efficient electrochemiluminescence (ECL). ${ }^{17}$ Herein we report the synthesis and characterization of the first examples of boron difluoride formazanate dimers, which contain conjugated and cross-conjugated electronic structures, as we work towards functional molecular materials based on formazanate ligands with optical properties in the farred/near-IR.

\section{Results and Discussion}

\section{Synthesis}

Meta- and para-substituted benzene-bridged bisformazans $\boldsymbol{p - 8}$ and $\boldsymbol{m - 8}$ were synthesized through the coupling of phenyl diazonium chloride salts with the corresponding meta- and para-benzene bridged bisphenylhydrazones $\boldsymbol{p - 9}$ and $\boldsymbol{m - 9}$ in a pyridine/dimethylformamide buffer according to published procedures (Scheme 1). ${ }^{18}$ The formazans were characterized by ${ }^{1} \mathrm{H}$ and ${ }^{13} \mathrm{C}$ NMR spectroscopy (Figures S1-S4), revealing diagnostic formazan NH shifts in the ${ }^{1} \mathrm{H}$ NMR spectra at $15.45 \mathrm{ppm}(\boldsymbol{p}-\mathbf{8})$ and $15.44 \mathrm{ppm}(\boldsymbol{m}-\mathbf{8})$, respectively. $\mathrm{BF}_{2}$ complexes $\boldsymbol{p}$-10 and $\boldsymbol{m}$-10 were synthesized by refluxing the appropriate bisformazan in toluene with 10 equivalents of $\mathrm{BF}_{3} \cdot \mathrm{OEt}_{2}$ and 6 equivalents of $\mathrm{NEt}_{3}$. 


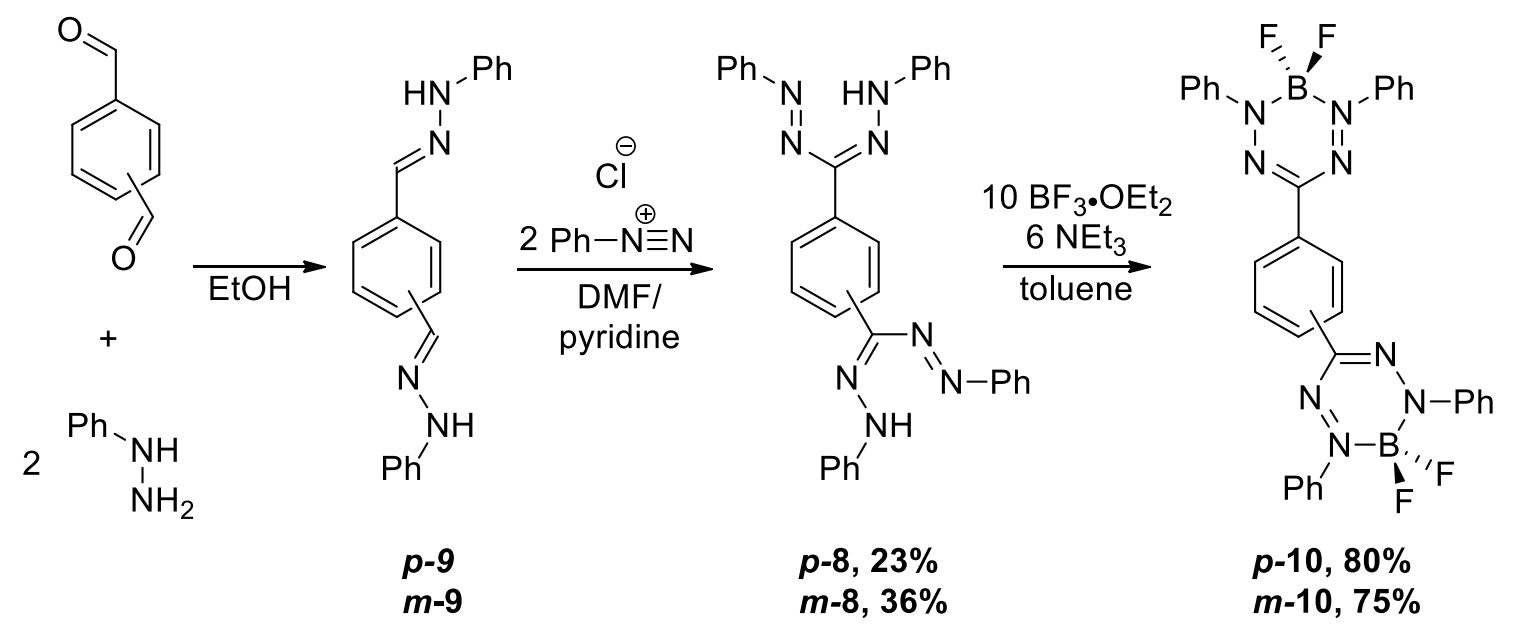

Scheme 1. Synthesis of benzene-bridged $\mathrm{BF}_{2}$ dimers $\boldsymbol{p}-\mathbf{1 0}$ and $\boldsymbol{m}$-10.

The resulting $\mathrm{BF}_{2}$ formazanate dimers $\boldsymbol{p}$-10 and $\boldsymbol{m}$-10 were characterized by ${ }^{1} \mathrm{H},{ }^{11} \mathrm{~B},{ }^{13} \mathrm{C}$ and ${ }^{19} \mathrm{~F}$ NMR spectroscopy (Figures 1 , S5-S6). The $\mathrm{BF}_{2}$ complexes showed characteristic 1:2:1 triplets in the ${ }^{11} \mathrm{~B}$ NMR spectra $(\boldsymbol{p}$-10: $-0.5 \mathrm{ppm} ; \boldsymbol{m}-\mathbf{1 0}:-0.5 \mathrm{ppm})$ and $1: 1: 1: 1$ quartets in the ${ }^{19} \mathrm{~F}$ NMR spectra (p-10: $-144.1 \mathrm{ppm} ; \boldsymbol{m}$-10: $-143.8 \mathrm{ppm}$ ) (Figure 1, insets). The aryl region of the ${ }^{1} \mathrm{H}$ NMR spectra of complexes $\boldsymbol{p}$-10 and $\boldsymbol{m}$-10 differ slightly from the ${ }^{1} \mathrm{H}$ NMR spectra of the respective formazans and the disappearance of the resonances above $15 \mathrm{ppm}$ indicate the loss of the NH protons. Each of these spectral features are consistent with those previously reported for the $\mathrm{BF}_{2}$ complex of the triphenylformazanate ligand $\mathbf{1 1} .^{16 \mathrm{c}}$

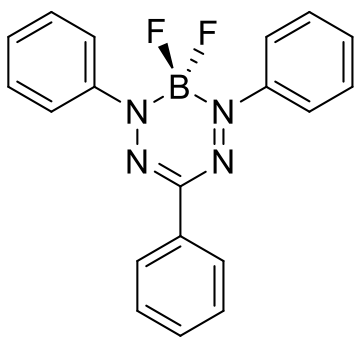




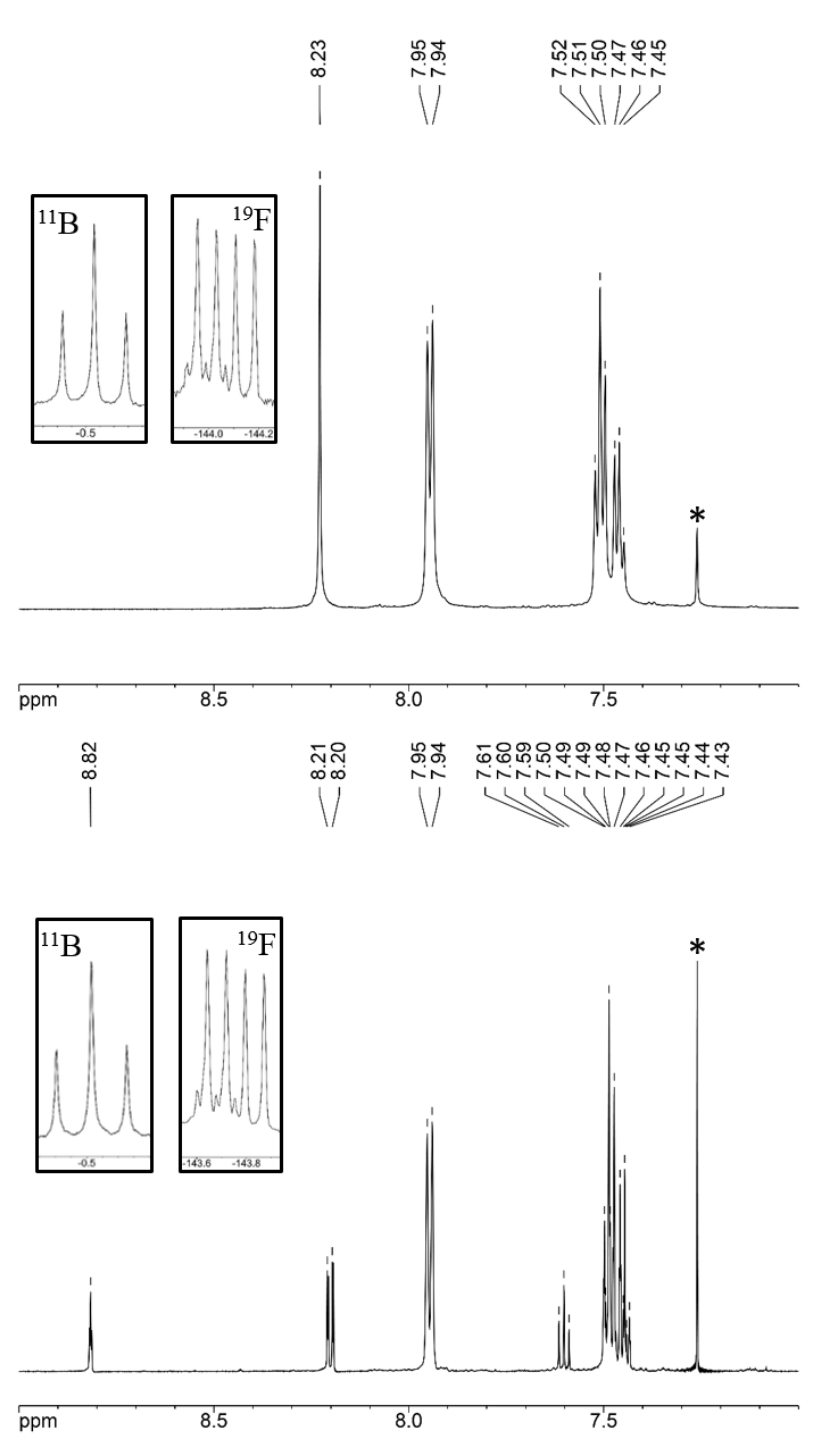

Figure 1. ${ }^{1} \mathrm{H}$ NMR spectra of a) $\boldsymbol{p}-\mathbf{1 0}$ and b) $\boldsymbol{m}-\mathbf{1 0}$ in $\mathrm{CDCl}_{3}$. Spectra are referenced to residual $\mathrm{CHCl}_{3}$ signals, which are denoted with asterisks. The corresponding ${ }^{19} \mathrm{~F}$ and ${ }^{11} \mathrm{~B}$ NMR spectra are shown as insets.

\section{X-ray Crystallography}

Single crystals of dimers $\boldsymbol{p} \mathbf{- 1 0}$ and $\boldsymbol{m - 1 0}$ suitable for X-ray diffraction studies were grown by slow evaporation of concentrated dichloromethane solution (Figures 2 and 3, Table 1). In both solid-state structures, the formazanate-benzene-formazanate $\pi$ frameworks are relatively planar with angles between the benzene bridge and the $\mathrm{N}_{4}$ planes of $10.46^{\circ}$ and $17.48^{\circ}$ in $\boldsymbol{p}-10$ and 
$8.79^{\circ}$ and $12.04^{\circ}$ in $\mathbf{m - 1 0}$. This planarity renders these compounds the perfect platform for probing electronic communication through meta- and para- benzene spacers. The $N$-phenyl substituents are moderately twisted in each structure, with torsion angles of $25.05-49.88^{\circ}(\boldsymbol{p}-10)$ and $18.77-40.44^{\circ}(\mathbf{m}-10)$ relative to the nearest formazanate moiety. The torsion is most likely the result of crystal packing effects. We also note that the formazanate backbones are delocalized, with all N-N, C-N and C-C bonds falling between the typical single and double bond lengths for the respective atoms involved. The $\mathrm{C}-\mathrm{C}$ bond lengths in the benzene bridges of p-10 and $\boldsymbol{m}$-10 are between 1.375(3) $\AA$ and 1.397(3) $\AA$, and are similar to other aromatic C-C bonds. ${ }^{19}$ For both dimers $\boldsymbol{p}$-10 and $\boldsymbol{m}$-10, one of the two $\mathrm{BF}_{2}$ formazanate moieties exists in a relatively planar conformation and the other in a 'dragonfly' conformation where the boron atom is displaced from the formazanate plane by more than $0.5 \AA$. We have previously reported that these two conformations differ in energy by only a few $\mathrm{kcal} / \mathrm{mol} .{ }^{16 a}$ 
a)
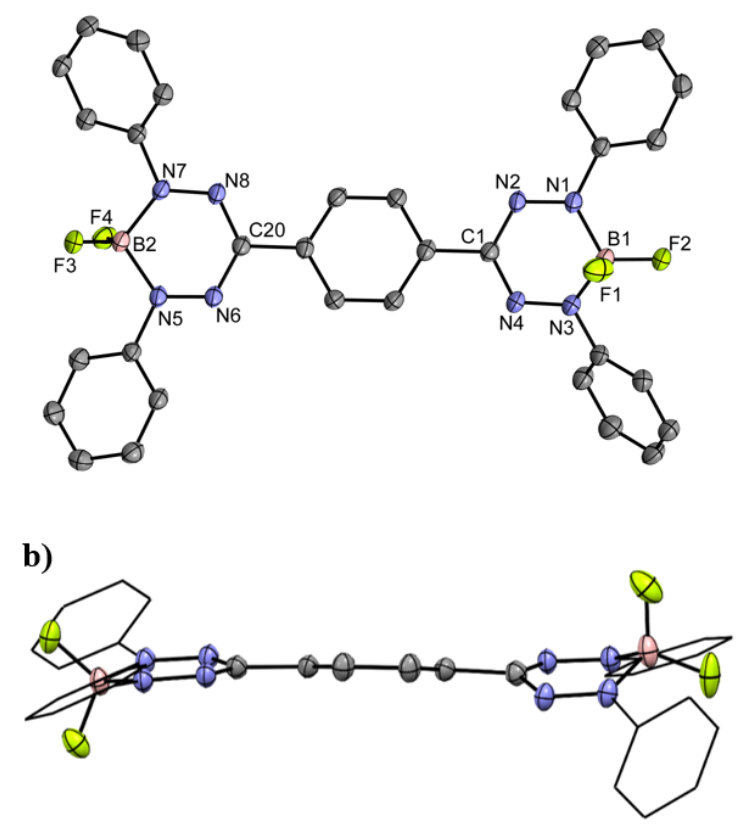

Figure 2. a) Top view and b) side view of the solid-state structure of $\mathrm{BF}_{2}$ formazanate dimer $\boldsymbol{p}$ 10. Anisotropic displacement ellipsoids are shown at 50\% probability and hydrogen atoms have been omitted for clarity. Only one of two very similar molecules in the asymmetric unit for $\boldsymbol{p}-\mathbf{1 0}$ is shown.
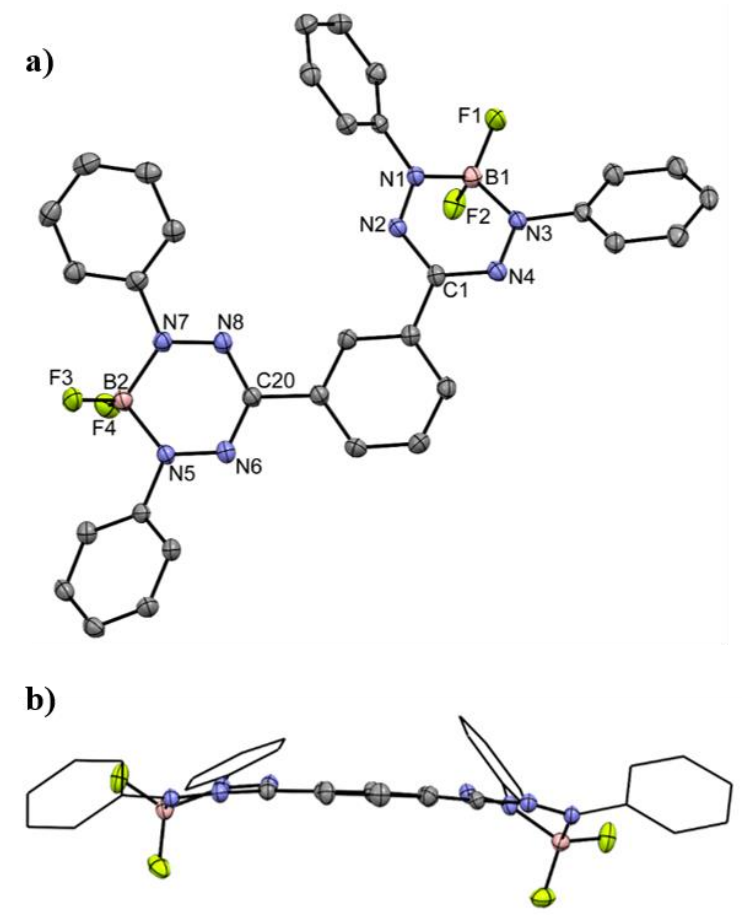

Figure 3. a) Top view and b) side view of the solid-state structure of $\mathrm{BF}_{2}$ formazanate dimer $\boldsymbol{m}$-10. Anisotropic displacement ellipsoids are shown at 50\% probability and hydrogen atoms have been omitted for clarity. 
Table 1. Selected bond lengths $(\AA)$ and angles (degrees) for $\mathrm{BF}_{2}$ formazanate dimers $\boldsymbol{p}$-10 and $\boldsymbol{m - 1 0}$, determined by single crystal X-ray diffraction.

\begin{tabular}{|c|c|c|}
\hline & $p-10$ & $m-10$ \\
\hline Boron displacement $^{a}$ & $0.159,0.503$ & $0.307,0.577$ \\
\hline \multirow{2}{*}{$N$-phenyl torsion angles ${ }^{b}$} & $25.05,31.59$ & $18.77,38.96$ \\
\hline & $27.46,49.88$ & $40.44,37.20$ \\
\hline Benzene bridge torsion angles ${ }^{c}$ & $10.46,17.48$ & $8.79,12.04$ \\
\hline $\mathrm{N} 1-\mathrm{N} 2$ & $1.297(2)$ & $1.3026(18)$ \\
\hline N3-N4 & $1.303(2)$ & $1.3077(18)$ \\
\hline N5-N6 & $1.305(2)$ & $1.3078(19)$ \\
\hline N7-N8 & $1.302(2)$ & $1.3130(19)$ \\
\hline N1-B1 & $1.562(3)$ & $1.559(2)$ \\
\hline N3-B1 & $1.556(3)$ & $1.553(2)$ \\
\hline N5-B2 & $1.563(3)$ & $1.556(2)$ \\
\hline N7-B2 & $1.546(3)$ & $1.556(2)$ \\
\hline $\mathrm{N} 2-\mathrm{C} 1$ & $1.346(3)$ & $1.343(2)$ \\
\hline N4-C1 & $1.336(2)$ & $1.340(2)$ \\
\hline N6-C20 & $1.337(3)$ & $1.341(2)$ \\
\hline $\mathrm{N} 8-\mathrm{C} 20$ & $1.344(2)$ & $1.339(2)$ \\
\hline $\mathrm{N} 1-\mathrm{N} 2-\mathrm{C} 1$ & $118.56(15)$ & $117.15(14)$ \\
\hline N3-N4-C1 & 118.61(16) & $119.12(14)$ \\
\hline N5-N6-C20 & $118.74(15)$ & $118.14(13)$ \\
\hline N7-N8-C20 & $116.89(16)$ & $117.02(14)$ \\
\hline $\mathrm{N} 2-\mathrm{C} 1-\mathrm{N} 4$ & $126.29(17)$ & $126.24(15)$ \\
\hline N6-C20-N8 & $124.78(17)$ & $124.37(15)$ \\
\hline
\end{tabular}

${ }^{a}$ Distance between B1/B2 and the nearest $\mathrm{N}_{4}$ plane. ${ }^{b}$ Angles between the plane defined by the $\mathrm{N} 1, \mathrm{~N} 3, \mathrm{~N} 5$ and N7 phenyl-substituents and the nearest $\mathrm{N}_{4}$ plane. ${ }^{c}$ Angles between the benzene bridge and the $\mathrm{N}_{4}$ plane.

\section{Cyclic Voltammetry}

Due to the poor solubility of compounds $p-\mathbf{1 0}$ and $\mathbf{m - 1 0}$ in acetonitrile, dichloromethane was used for the cyclic voltammetry studies. The cyclic voltammograms of compounds $\boldsymbol{p}-\mathbf{1 0}, \boldsymbol{m}-\mathbf{1 0}$ and $\mathbf{1 1}$ are shown in Figure $4 . \mathrm{BF}_{2}$ formazanate dimers $\boldsymbol{m - 1 0}$ and $\boldsymbol{p}$-10 each undergo reversible electrochemical reduction at $\mathrm{E}_{1 / 2, \mathrm{red} 1}=-0.90 \mathrm{~V}(\boldsymbol{p}-\mathbf{1 0})$ and $-0.92 \mathrm{~V}(\boldsymbol{m}-\mathbf{1 0})$ corresponding to the transfer of two electrons (Table 2). Both dimers undergo a second irreversible electrochemical reduction at $\mathrm{E}_{\mathrm{pc}, \text { red2 }}=-1.78 \mathrm{~V}(\boldsymbol{p}$-10) and $-1.89 \mathrm{~V}(\boldsymbol{m - 1 0})$ also consistent with a two-electron transfer. The first reversible reduction of dimers $\boldsymbol{p - 1 0}$ and $\boldsymbol{m - 1 0}$ corresponds to the formation of 
the bis-radical anion form of the dimer, as depicted in Scheme 2. The second reduction of compounds $\boldsymbol{p - 1 0}$ and $\boldsymbol{m - 1 0}$ corresponds to the bis-radical anions being transformed into bisdianions. Monomer 11 displayed similar electrochemical properties $\left(\mathrm{E}_{1 / 2, \mathrm{red} 1}=-0.93 \mathrm{~V}\right.$ and $\mathrm{E}_{\mathrm{pc}}$, red2 $=-1.84 \mathrm{~V}$ ), with each reduction corresponding to transfer of a single electron. We have previously shown that the electrochemical properties of monomeric $\mathrm{BF}_{2}$ formazanate complexes are sensitive to the presence of electron-withdrawing and electron-donating carbon substituents. ${ }^{16 \mathrm{c}} \mathrm{We}$ therefore attribute the relative ease of reduction (less negative potentials) associated with $\boldsymbol{p - 1 0}$ to the electron withdrawing nature of the $\mathrm{BF}_{2}$ formazanate moieties, which is enhanced in the para-substituted dimer.

The second reduction waves for $p$-10, $\boldsymbol{m - 1 0}$ and $\mathbf{1 1}$ were not reversible in dichloromethane, despite the second reduction of monomer $\mathbf{1 1}$ being fully reversible in acetonitrile. ${ }^{16 \mathrm{c}}$ The anodic peak current associated with the second reduction wave increased as the scan rate increased (Figures S7-S9), indicating that the irreversibility may arise due to a competing chemical reaction, which oxidizes the bis-dianions to bis-radical anions. Initially, we considered the possibility that the electrogenerated bis-dianions could undergo a comproportionation reaction with neutral $\mathrm{BF}_{2}$ complexes to generate two equivalents of bisradical anions (e.g., $\mathrm{LBF}_{2}{ }^{2-}+\mathrm{LBF}_{2} \rightarrow 2 \mathrm{LBF}_{2}{ }^{-}$). However, based on the symmetry of the anodic and cathodic peak currents associated with the first reduction, we do not feel that this is the case. ${ }^{20}$ We conclude that the electrogenerated dianions are oxidized back to their radical anion forms within the electrochemical cell, although the identity of the oxidant remains elusive. 


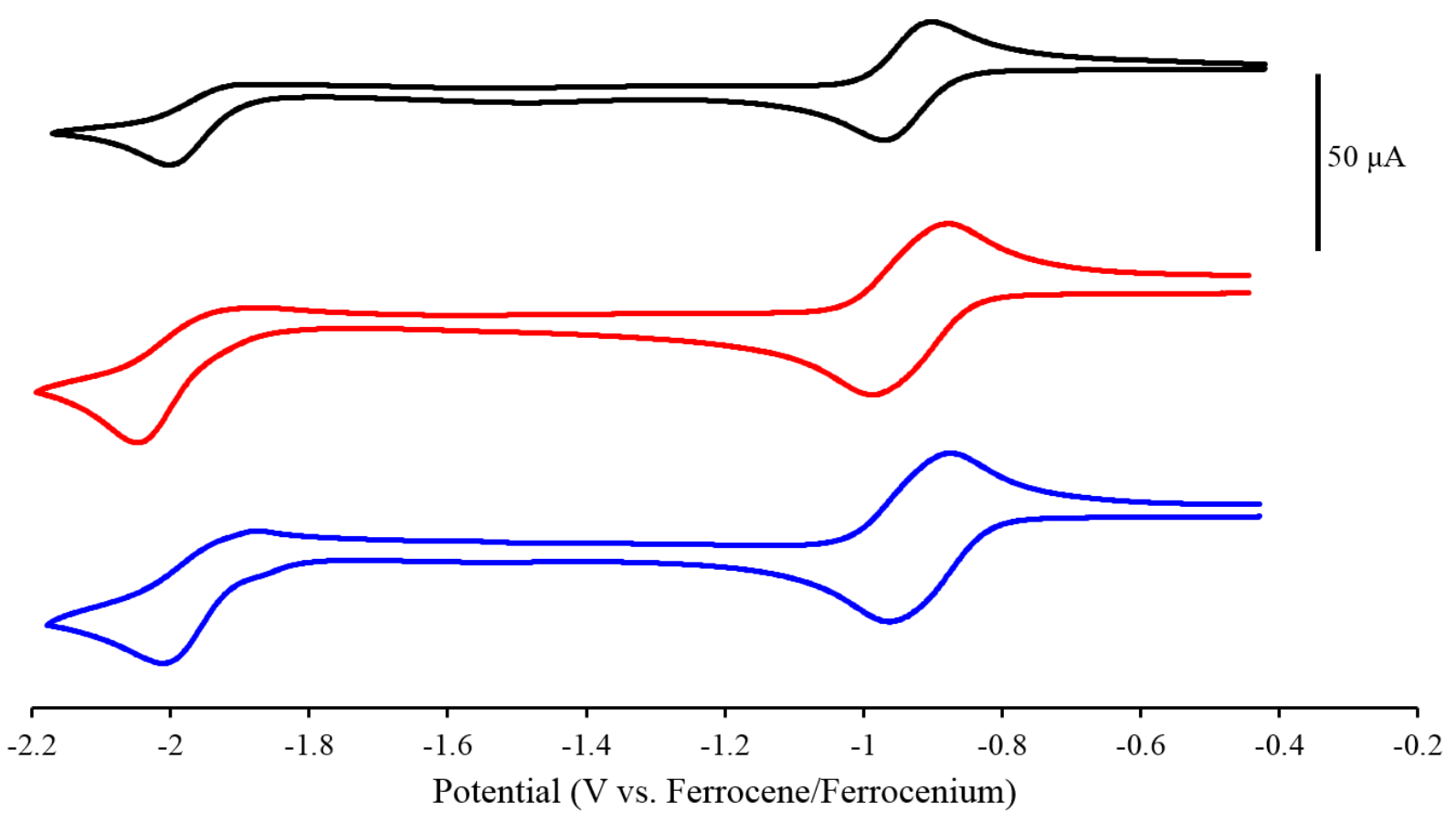

Figure 4. Cyclic voltammograms of $p-10$ (blue), $\boldsymbol{m - 1 0}$ (red) and $\mathbf{1 1}$ (black) recorded at $100 \mathrm{mV} \mathrm{s}^{-1}$ in $1 \mathrm{mM}$ dichloromethane solutions containing $0.1 \mathrm{M}$ tetrabutylammonium hexafluorophosphate as supporting electrolyte.

Due to the broad appearance of the reduction peaks in the cyclic voltammograms of dimers $\boldsymbol{p - 1 0}$ and $\boldsymbol{m - 1 0}$ relative to monomer $\mathbf{1 1}$, we believe each process involves two distinct one-electron reductions (one electron for each of the $\mathrm{BF}_{2}$ formazanate moieties). However, we were unable to resolve each wave, even when square wave or differential pulse voltammetry were employed. All three complexes also undergo irreversible electrochemical oxidation within the solvent window (Figure S10). 

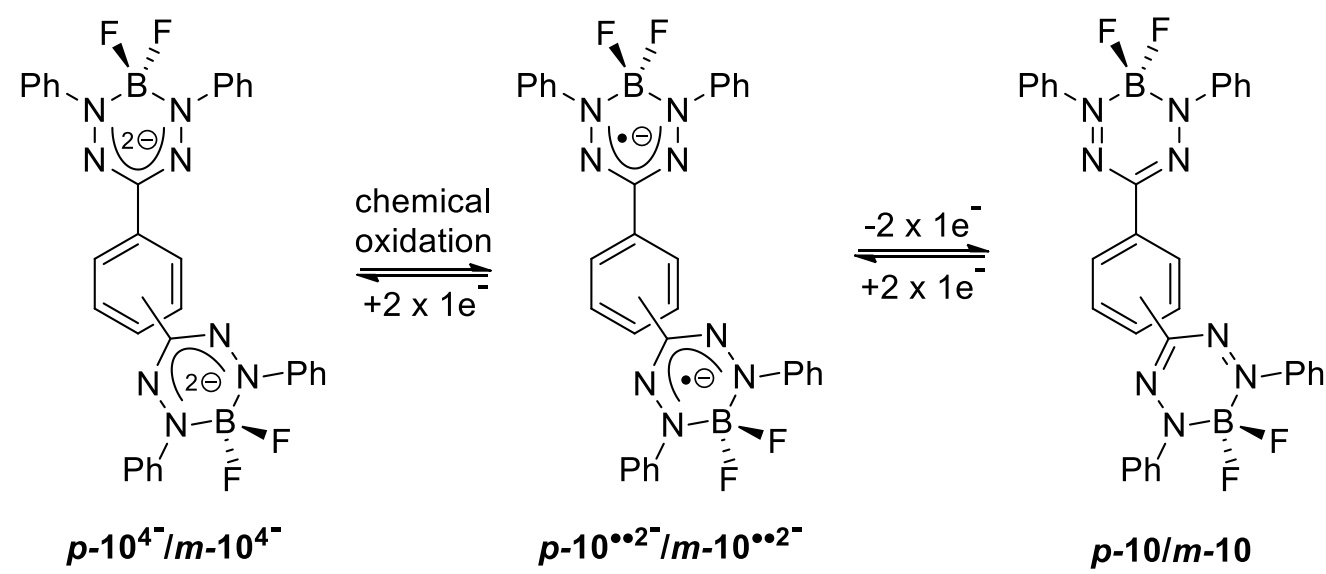

Scheme 2. Electrochemical/chemical reactions for $\boldsymbol{p - 1 0}$ and $\boldsymbol{m - 1 0 .}$

Closely related benzene-bridged diradicals $p-12$ and $\boldsymbol{m - 1 2}$ have been shown to undergo reversible electrochemical oxidation and reduction to their closed shell bis-cation and bis-anion forms. ${ }^{21}$ In these systems, electrochemical reduction occurred in two well-resolved steps, which supports the interpretation of our results.<smiles>CCCN1N=C(c2ccc(C3=NN(C(C)C)C(=O)N(C(C)C)N3)cc2)NN(C(C)C)C1=O</smiles>

p-12<smiles>CCCN1N=C(c2cccc(C3=NN(C(C)C)C(=O)N(C(C)C)N3)c2)NN(C(C)C)C1=O</smiles>

$m-12$

\section{UV-Vis Absorption and Emission Spectroscopy}

Qualitatively, $\boldsymbol{m - 1 0}$ and $\mathbf{1 1}$ have very similar absorption and emission spectra. In dichloromethane, $\boldsymbol{m - 1 0}$ has a wavelength of maximum absorption of $507 \mathrm{~nm}$, which is very 
similar to that of monomer $11\left(\lambda_{\max }=509 \mathrm{~nm}\right)$. Monomer 11 is highly absorbing, with a molar

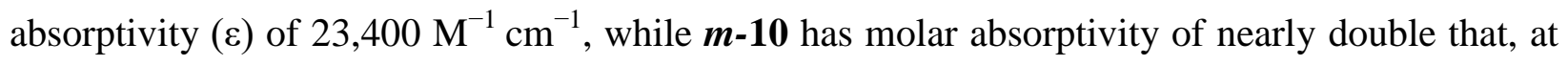
$39,600 \mathrm{M}^{-1} \mathrm{~cm}^{-1}$ due to the presence of two boron difluoride formazanate moieties. In comparison, complex $\boldsymbol{p}$-10 has a higher wavelength of maximum absorption of $523 \mathrm{~nm}$ in dichloromethane and is strongly absorbing $\left(\varepsilon=30,900 \mathrm{M}^{-1} \mathrm{~cm}^{-1}\right)$ (Figure 5, Table 2). The molar absorptivities observed for the dimeric complexes were solvent dependent. We postulate that this behavior may arise due to the influence of solvent polarity on the relative orientation of the $\mathrm{BF}_{2}$ formazanate moieties in dimers $\boldsymbol{p} \mathbf{- 1 0}$ and $\boldsymbol{m} \mathbf{- 1 0}$, which is not a factor for monomeric complex $\mathbf{1 1}$.

Time-dependent density functional theory (DFT) calculations have previously shown that the highest occupied molecular orbital (HOMO) and lowest unoccupied molecular orbital (LUMO) are the dominant orbital pair involved in the lowest energy excitation in 11. ${ }^{16 \mathrm{c}}$ DFT calculations also showed that the HOMO of $\mathbf{1 1}$ is highly delocalized and includes significant orbital density on the phenyl ring appended to the carbon of the formazanate backbone. Despite the lack of orbital density on the same phenyl substituent in the LUMO orbital of 11, it is reasonable to expect red-shifted absorption and emission maxima for $\boldsymbol{p - 1 0}$ on the basis that the HOMO for $\boldsymbol{p - 1 0}$ will be highly delocalized through the conjugated para-benzene spacer, while the HOMO's for monomer $\mathbf{1 1}$ and cross-conjugated dimer $\mathbf{m - 1 0}$ will not extend beyond their carbon-bound benzene substituents. ${ }^{16 \mathrm{c}}$

$\mathrm{BF}_{2}$ complexes $\boldsymbol{p}-\mathbf{1 0}, \boldsymbol{m}-\mathbf{1 0}$ and $\mathbf{1 1}$ are weakly emissive, with wavelengths of maximum emission of 654, 627 and $630 \mathrm{~nm}$ and modest emission quantum yields of $0.08,0.03$ and 0.01 in dichloromethane, respectively. Each compound exhibits a large Stokes shift, ranging from 120 to $131 \mathrm{~nm}\left(v_{\mathrm{ST}}=3773-3830 \mathrm{~cm}^{-1}\right)$. It is noteworthy that the emission quantum yields increase for the dimers, relative to monomer 11. It has been shown that the emission quantum yield of para- 
benzene bridged BODIPY dimers $\mathbf{6}$ is significantly reduced relative to phenyl-substituted monomer 7. ${ }^{14 \mathrm{~b}}$ A major factor contributing to the decreased emission intensity in BODIPY dimer 6 is the small emission Stokes shifts observed for the monomeric units $\left(v_{\mathrm{ST}}=25 \mathrm{~nm}, 906 \mathrm{~cm}^{-1}\right)$, which leads to reabsorption of emitted photons by the fluorophore in close proximity within the dimer framework. In the case of dimers $\boldsymbol{p - 1 0}$ and $\boldsymbol{m - 1 0}$, the large Stokes shifts result in minimal overlap between absorption and emission bands and limit reabsorption of emitted photons by the dimer pairs.
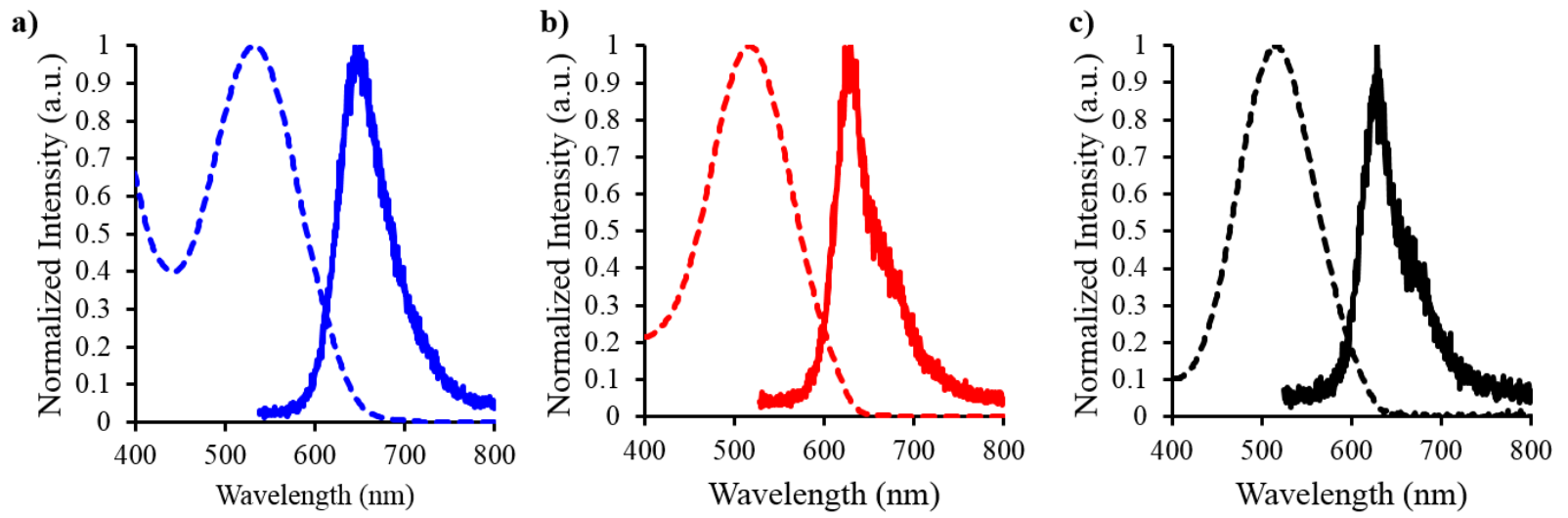

Figure 5. UV-vis absorption spectra (dashed lines) and emission spectra (solid lines) of a) $\boldsymbol{p}$-10, b) $\mathbf{m - 1 0}$ and c) $\mathbf{1 1}$, recorded in $10^{-5} \mathrm{M}$ degassed toluene solutions.

Table 2. Solution characterization data for $\mathrm{BF}_{2}$ complexes $\boldsymbol{p}-\mathbf{1 0}, \boldsymbol{m - 1 0}$ and 11.

\begin{tabular}{|c|c|c|c|c|c|c|c|c|c|}
\hline & Solvent & $\begin{array}{l}\lambda_{\max } \\
(\mathrm{nm})\end{array}$ & $\begin{array}{l}\varepsilon\left(\mathrm{M}^{-1}\right. \\
\left.\mathrm{cm}^{-1}\right)\end{array}$ & $\begin{array}{l}\lambda_{\mathrm{em}} \\
(\mathrm{nm})\end{array}$ & $\Phi_{\mathrm{f}}$ & $\begin{array}{l}U_{\mathrm{ST}} \\
(\mathrm{nm})\end{array}$ & $\begin{array}{l}\left.\mathrm{UST}_{\mathrm{ST}}^{-1}\right) \\
\left(\mathrm{cm}^{-1}\right)\end{array}$ & $\begin{array}{l}\mathrm{E}_{1 / 2, \text { red1 }}{ }^{a} \\
(\mathrm{~V})\end{array}$ & $\begin{array}{l}\mathrm{E}_{\mathrm{pc}, \text { red2 }}{ }^{b} \\
\text { (V) }\end{array}$ \\
\hline \multirow{3}{*}{$p-10$} & THF & 523 & 26,700 & 650 & 0.03 & 127 & 3736 & \multirow{3}{*}{-0.90} & \multirow{3}{*}{-1.78} \\
\hline & Toluene & 534 & 28,800 & 649 & 0.04 & 115 & 3318 & & \\
\hline & $\mathrm{CH}_{2} \mathrm{Cl}_{2}$ & 523 & 30,900 & 654 & 0.08 & 131 & 3830 & & \\
\hline \multirow{3}{*}{$m-10$} & THF & 509 & 35,800 & 625 & $<0.01$ & 116 & 3646 & \multirow{3}{*}{-0.92} & \multirow{3}{*}{-1.82} \\
\hline & Toluene & 518 & 30,200 & 628 & 0.01 & 110 & 3381 & & \\
\hline & $\mathrm{CH}_{2} \mathrm{Cl}_{2}$ & 507 & 39,600 & 627 & 0.03 & 120 & 3775 & & \\
\hline \multirow{3}{*}{11} & $\mathrm{THF}$ & 509 & 22,500 & 627 & 0.01 & 118 & 3697 & \multirow{3}{*}{-0.93} & \multirow{3}{*}{-1.84} \\
\hline & Toluene & 517 & 23,800 & 626 & $<0.01$ & 109 & 3368 & & \\
\hline & $\mathrm{CH}_{2} \mathrm{Cl}_{2}$ & 509 & 23,400 & 630 & 0.01 & 121 & 3773 & & \\
\hline
\end{tabular}

\footnotetext{
${ }^{a}$ Reversible reduction, half wave potential reported. ${ }^{b}$ Irreversible reduction, cathodic peak
} potential reported. 


\section{Conclusion}

We have prepared the first examples of $\mathrm{BF}_{2}$ formazanate dimers and studied their electrochemical and light absorbing/emitting properties. The electrochemical properties of dimers $\boldsymbol{p - 1 0}$ and $\boldsymbol{m - 1 0}$ were closely related to those of monomer $\mathbf{1 1}$, with each $\mathrm{BF}_{2}$ formazanate moiety undergoing sequential one-electron reduction to the corresponding radical anion and dianion forms. In comparison to monomer 11, the para-substituted benzene-bridged $\mathrm{BF}_{2}$ formazanate dimer $(\boldsymbol{p}$-10) exhibited optical properties consistent with extended $\pi$ conjugation, which caused a red-shift in the wavelengths of maximum absorption and emission and an increase in emission quantum yield. The latter characteristic was in sharp contrast to the emission behavior of closely related BODIPY dimers, where emission quantum yields were much lower than those observed for monomeric analogs. On the other hand, the meta-substituted benzene-bridged $\mathrm{BF}_{2}$ formazanate dimer $(\boldsymbol{m}-\mathbf{1 0})$ displayed characteristics consistent with a crossconjugated electronic structure and essentially behaved as two independent $\mathrm{BF}_{2}$ formazanate moieties. The wavelengths of maximum absorption and emission for $\boldsymbol{m - 1 0}$ and $\mathbf{1 1}$ were very similar and the molar absorptivity of $\mathbf{m - 1 0}$ was effectively double that observed for monomer $\mathbf{1 1}$. This work has demonstrated the potential of $\mathrm{BF}_{2}$ formazanate complexes as far-red/near-IR dyes, largely due to their high Stokes shifts $\left(v_{\mathrm{ST}}=110-131 \mathrm{~nm}, 3318-3830 \mathrm{~cm}^{-1}\right)$. Our future work in this area will focus on increasing the emission intensity of $\mathrm{BF}_{2}$ formazanate complexes through judicious substitution of the formazanate carbon and exploiting the properties of $\mathrm{BF}_{2}$ formazanate complexes in multifunctional $\pi$-conjugated polymers.

\section{Acknowledgements}

The authors thank the Natural Sciences and Engineering Research Council (NSERC) of Canada Discovery Grants (J. B. G.) and Canada Graduate Scholarships (S. M. B.) programs and The 
University of Western Ontario for the financial support. We also thank Prof. Elizabeth R. Gillies and Prof. Mark S. Workentin for access to instruments in their labs.

\section{Experimental Section}

\section{General Considerations}

All reactions and manipulations were carried out under a nitrogen atmosphere using standard Schlenk techniques unless otherwise stated. Solvents were obtained from Caledon Laboratories, dried using an Innovative Technologies Inc. solvent purification system, collected under vacuum and stored under a nitrogen atmosphere over $4 \AA$ molecular sieves. All reagents were purchased from Sigma-Aldrich or Alfa Aesar and used as received. The synthesis of formazans $\boldsymbol{p - 8}$ and $\boldsymbol{m - 8}$ have been reported previously, ${ }^{18}$ however, details of their synthesis and characterization were limited. We have therefore included full experimental details for these compounds. The synthesis of triphenyl formazan and the corresponding $\mathrm{BF}_{2}$ complex 11 have been reported previously. ${ }^{16 \mathrm{c}}$

NMR Spectra were recorded on $400 \mathrm{MHz}\left({ }^{1} \mathrm{H}: 399.8 \mathrm{MHz},{ }^{11} \mathrm{~B}: 128.3 \mathrm{MHz},{ }^{19} \mathrm{~F}: 376.1\right.$ $\mathrm{MHz})$ or $600 \mathrm{MHz}\left({ }^{1} \mathrm{H}: 599.5 \mathrm{MHz},{ }^{13} \mathrm{C}: 150.8 \mathrm{MHz}\right)$ Varian INOVA instruments. ${ }^{1} \mathrm{H}$ NMR spectra were referenced to residual $\mathrm{CHCl}_{3}(7.26 \mathrm{ppm})$ and ${ }^{13} \mathrm{C} \mathrm{NMR}$ spectra were referenced to $\mathrm{CDCl}_{3}(77.2 \mathrm{ppm}) .{ }^{11} \mathrm{~B}$ spectra were referenced to $\mathrm{BF}_{3} \cdot \mathrm{OEt}_{2}$ at $0 \mathrm{ppm}$ and ${ }^{19} \mathrm{~F}$ spectra were referenced to $\mathrm{CFCl}_{3}$ at $0 \mathrm{ppm}$. Mass spectrometry data were recorded in positive-ion mode using a high-resolution Finnigan MAT 8200 spectrometer using electron impact ionization. UV-vis spectra were recorded using a Cary 300 Scan instrument. Four separate concentrations were run for each sample and molar extinction coefficients were determined from the slope of a plot of absorbance against concentration. Infrared spectra were recorded on a $\mathrm{KBr}$ disk using a Bruker Vector 33 FT-IR spectrometer. Emission spectra were obtained using a Photon Technology International QM-4 SE spectrofluorometer. Excitation wavelengths were chosen based on $\lambda_{\max }$ 
from the respective UV-vis absorption spectrum in the same solvent. Emission quantum yields were estimated relative to ruthenium tris(bipyridine) hexafluorophosphate by previously described methods and corrected for wavelength dependent detector sensitivity (Figure S11). ${ }^{22}$

\section{Electrochemical Methods}

Cyclic voltammetry experiments were performed with a Bioanalytical Systems Inc. (BASi) Epsilon potentiostat and analyzed using BASi Epsilon software. Electrochemical cells consisted of a three-electrode setup including a glassy carbon working electrode, platinum wire counter electrode and silver wire pseudo reference electrode. Experiments were run at various scan rates (100-2000 $\left.\mathrm{mV} \mathrm{s}^{-1}\right)$ in degassed dichloromethane solutions of the analyte $(\sim 1 \mathrm{mM})$ and supporting electrolyte (0.1 $\quad$ M tetrabutylammonium hexafluorophosphate). Cyclic voltammograms were referenced against an internal standard $(\sim 1 \mathrm{mM}$ ferrocene $)$ and corrected for internal cell resistance using the BASi Epsilon software.

\section{X-ray Crystallography Details}

Single crystals of dimers $\boldsymbol{p - 1 0}$ and $\boldsymbol{m - 1 0}$ suitable for X-ray diffraction studies were grown by slow evaporation of a concentrated dichloromethane solutions. The samples were mounted on Mitegen polyimide micromounts with a small amount of Paratone $\mathrm{N}$ oil. All X-ray measurements were made on a Nonius KappaCCD Apex2 (p-10) or Bruker Kappa Axis Apex2 (m-10) diffractometer at a temperature of $110 \mathrm{~K}$. The data collection strategy included a number of $\omega$ and $\varphi$ scans which collected data over a range of angles, $2 \theta$. The frame integrations were performed using SAINT. ${ }^{23}$ The resulting raw data was scaled and absorption corrected using a multi-scan averaging of symmetry equivalent data using SADABS. ${ }^{24}$ The structures were solved by using a dual space methodology using the SHELXT program. ${ }^{25}$ All non-hydrogen atoms were obtained from the initial solution. The hydrogen atoms were introduced at idealized 
positions and were allowed to refine isotropically. The structural models were fit to the data using full matrix least-squares based on $F^{2}$. The calculated structure factors included corrections for anomalous dispersion from the usual tabulation. The structures were refined using the SHELXL-2014 program from the SHELX suite of crystallographic software. ${ }^{26}$ See Table 3 and the Cambridge Crystallographic Data Centre (CCDC, 1401466 and 1401467) for additional crystallographic data.

Table 3. X-ray diffraction data collection and refinement details for $\mathrm{BF}_{2}$ formazanate dimers $\boldsymbol{p}$ 10 and $\boldsymbol{m - 1 0 .}$

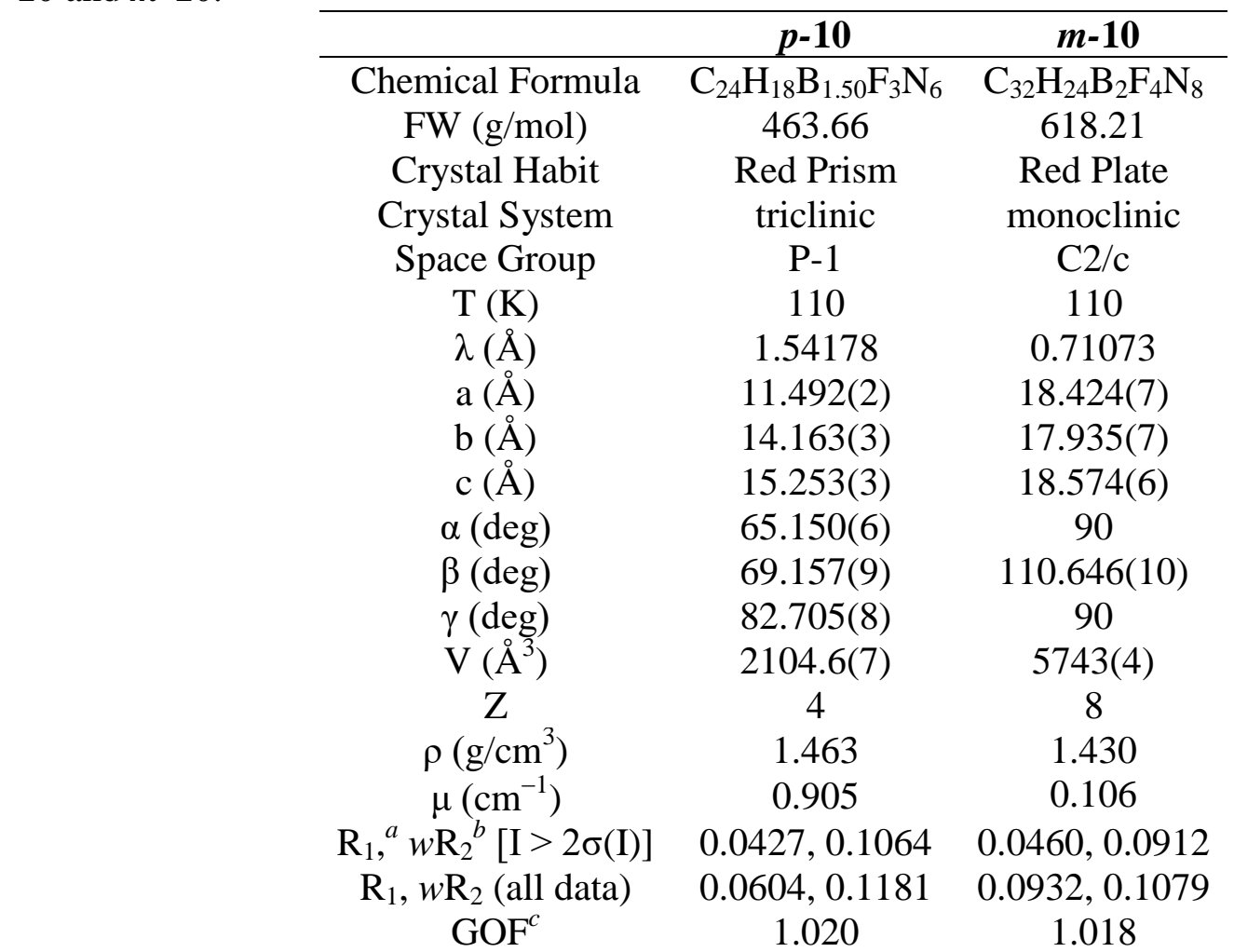

${ }^{a} \mathrm{R}_{1}=\Sigma\left(\left|\mathrm{F}_{\mathrm{o}}\right|-\left|\mathrm{F}_{\mathrm{c}}\right|\right) / \overline{/ \Sigma \mathrm{F}_{\mathrm{o}},{ }^{b} w \mathrm{R}_{2}=\left[\Sigma\left(w\left(\mathrm{~F}_{\mathrm{o}}{ }^{2}-\mathrm{F}_{\mathrm{c}}{ }^{2}\right)^{2}\right) / \Sigma\left(w \mathrm{~F}_{\mathrm{o}}{ }^{4}\right)\right]^{1 / 2},{ }^{c} \mathrm{GOF}=[\Sigma}\left(w\left(\mathrm{~F}_{\mathrm{o}}{ }^{2}-\mathrm{F}_{\mathrm{c}}{ }^{2}\right)^{2}\right) /$ (No. of reflns. - No. of params. ) $]^{1 / 2}$

\section{Representative procedure for the preparation of formazans $p-8$ and $m-8$ :}

\section{Formazan Dimer $p-8$}

In air, phenyl hydrazine $(5.08 \mathrm{~g}, 4.62 \mathrm{~mL}, 47.0 \mathrm{mmol})$ was dissolved in ethanol $(30 \mathrm{~mL})$, before terephthalaldehyde $(1.50 \mathrm{~g}, 22.0 \mathrm{mmol})$ was added and the solution allowed to stir for $10 \mathrm{~min}$. At 
which time, a light yellow precipitate had formed. Dimethylformamide $(100 \mathrm{~mL})$ and pyridine $(100 \mathrm{~mL})$ were added and the mixture was cooled in an ice bath to $0{ }^{\circ} \mathrm{C}$. In a separate flask, aniline $(5.12 \mathrm{~g}, 5.02 \mathrm{~mL}, 55.0 \mathrm{mmol})$ and concentrated hydrochloric acid $(11.8 \mathrm{~mL})$ were mixed in water $(30 \mathrm{~mL})$ and cooled in an ice bath. A cooled solution of sodium nitrite $(4.00 \mathrm{~g}, 58.0$ mmol) in water $(10 \mathrm{~mL})$ was added slowly to the amine solution. This mixture was left to stir at $0{ }^{\circ} \mathrm{C}$ for $30 \mathrm{~min}$, at which time it was added dropwise to the $\mathrm{DMF} /$ pyridine mixture described above over a 10 min period. The resulting solution was stirred for $18 \mathrm{~h}$, during which time a dark red/brown precipitate formed. The dark red/brown solid was isolated by vacuum filtration, washed with water and methanol and purified by flash chromatography (dichloromethane, neutral alumina) to afford formazan $\boldsymbol{p - 8}$ as a dark red/brown microcrystalline solid. Yield $=2.60$ g, 23\%. Melting point $=196-198{ }^{\circ} \mathrm{C} .{ }^{1} \mathrm{H}$ NMR $\left(599.5 \mathrm{MHz}, \mathrm{CDCl}_{3}\right) \delta 15.45(\mathrm{~s}, 2 \mathrm{H}, \mathrm{NH}), 8.24$ $(\mathrm{s}, 4 \mathrm{H}, \operatorname{aryl} \mathrm{CH}), 7.73\left(\mathrm{~d},{ }^{3} J_{\mathrm{HH}}=7 \mathrm{~Hz}, 8 \mathrm{H}, \operatorname{aryl} \mathrm{CH}\right), 7.48\left(\mathrm{t},{ }^{3} \mathrm{~J}_{\mathrm{HH}}=7 \mathrm{~Hz}, 8 \mathrm{H}, \operatorname{aryl} \mathrm{CH}\right), 7.30(\mathrm{t}$, $\left.{ }^{3} J_{\mathrm{HH}}=7 \mathrm{~Hz}, 4 \mathrm{H}, \operatorname{aryl} \mathrm{CH}\right) .{ }^{13} \mathrm{C}\left\{{ }^{1} \mathrm{H}\right\} \mathrm{NMR}\left(100.6 \mathrm{MHz}, \mathrm{CDCl}_{3}\right): \delta 148.2,136.9,129.7,127.7$, 126.1, 119.1. After 10,000 scans on a $600 \mathrm{MHz}$ NMR spectrometer, only 6 signals were observed due to the poor solubility of $\boldsymbol{p - 8}$ in common organic solvents. FT-IR (KBr): 3267 (br, s), 3035 (m), 3006 (m), 1598 (s), 1509 (s), 1455 (m), 1405 (m), 1351 (s), $1311(\mathrm{w}), 1221$ (s) $\mathrm{cm}^{-1}$. UV-vis (toluene): $\lambda_{\max }=500 \mathrm{~nm}\left(\varepsilon=28,900 \mathrm{M}^{-1} \mathrm{~cm}^{-1}\right)$. Mass Spec. (EI, +ve mode): exact mass calculated for $\left[\mathrm{C}_{32} \mathrm{H}_{26} \mathrm{~N}_{8}\right]^{+}: 522.2280$; exact mass found: 522.2280 ; difference: $-0.15 \mathrm{ppm}$.

\section{Formazan Dimer $m-8$}

In air, from $11.2 \mathrm{mmol}$ aldehyde and $28.0 \mathrm{mmol}$ hydrazine: Yield $=1.68 \mathrm{~g}, 36 \%$. Melting point $=$ 175-177 ${ }^{\circ} \mathrm{C} .{ }^{1} \mathrm{H}$ NMR $\left(599.5 \mathrm{MHz}, \mathrm{CDCl}_{3}\right) \delta 15.44(\mathrm{~s}, 2 \mathrm{H}, \mathrm{NH}), 9.03(\mathrm{~s}, 1 \mathrm{H}$, aryl $\mathrm{CH}), 8.14(\mathrm{~d}$, ${ }^{3} J_{\mathrm{HH}}=8 \mathrm{~Hz}, 2 \mathrm{H}$, aryl $\left.\mathrm{CH}\right), 7.76\left(\mathrm{~d},{ }^{3} J_{\mathrm{HH}}=8 \mathrm{~Hz}, 8 \mathrm{H}, \operatorname{aryl} \mathrm{CH}\right), 7.52\left(\mathrm{t},{ }^{3} J_{\mathrm{HH}}=8 \mathrm{~Hz}, 1 \mathrm{H}\right.$, aryl

$\mathrm{CH}), 7.50-7.47(\mathrm{~m}, 8 \mathrm{H}$, aryl $\mathrm{CH}), 7.31\left(\mathrm{t},{ }^{3} J_{\mathrm{HH}}=7 \mathrm{~Hz}, 4 \mathrm{H}\right.$, aryl $\left.\mathrm{CH}\right) .{ }^{13} \mathrm{C}\left\{{ }^{1} \mathrm{H}\right\}$ NMR $(100.6$ 
$\left.\mathrm{MHz}, \mathrm{CDCl}_{3}\right): \delta 148.2,141.1,137.6,129.6,128.8,127.6,125.1,123.6,119.0$. FT-IR $(\mathrm{KBr}):$ 3272 (br, s), 3026 (m), 3019 (m), 1598 (s), 1510 (s), 1455 (m), 1451 (m), 1343 (m), 1217 (s) $\mathrm{cm}^{-1}$. UV-vis (toluene): $\lambda_{\max }=496 \mathrm{~nm}\left(\varepsilon=39,200 \mathrm{M}^{-1} \mathrm{~cm}^{-1}\right)$. Mass Spec. (EI, +ve mode): exact mass calculated for $\left[\mathrm{C}_{32} \mathrm{H}_{26} \mathrm{~N}_{8}\right]^{+}: 522.2280$; exact mass found: 522.2285 ; difference: $+0.80 \mathrm{ppm}$.

Representative procedure for the preparation of formazanate $\mathrm{BF}_{2}$ complexes $p-10$ and $m$ -

10:

Formazanate $\mathrm{BF}_{2}$ Dimer $p$-10

Formazan $\boldsymbol{p - 8}(1.00 \mathrm{~g}, 1.91 \mathrm{mmol})$ was dissolved in dry toluene $(100 \mathrm{~mL})$ and triethylamine $(1.16 \mathrm{~g}, 1.60 \mathrm{~mL}, 11.4 \mathrm{mmol})$ was added slowly, before the solution was allowed to stir for 10 min. Boron trifluoride diethyl etherate $(2.72 \mathrm{~g}, 2.36 \mathrm{~mL}, 19.1 \mathrm{mmol})$ was then added and the solution heated at $80{ }^{\circ} \mathrm{C}$ for $18 \mathrm{~h}$. The solution gradually changed colour from dark red to dark purple during this time. The reaction was then cooled to $20{ }^{\circ} \mathrm{C}$ and deionized water $(10 \mathrm{~mL})$ was added to quench any excess reactive boron-containing compounds. The red/purple toluene fraction was then washed with deionized water $(3 \times 50 \mathrm{~mL})$, dried over $\mathrm{MgSO}_{4}$, gravity filtered and concentrated in vacuo. The resulting residue was purified by flash chromatography (dichloromethane, neutral alumina) to afford $\mathrm{BF}_{2}$ complex $\boldsymbol{p}-\mathbf{1 0}$ as a dark purple microcrystalline solid. Yield $=0.94 \mathrm{~g}, 80 \%$. Melting point $=192-194{ }^{\circ} \mathrm{C} .{ }^{1} \mathrm{H}$ NMR $\left(599.5 \mathrm{MHz}, \mathrm{CDCl}_{3}\right) \delta 8.23$ (s, 4H, aryl $\mathrm{CH}), 7.94\left(\mathrm{~d},{ }^{3} J_{\mathrm{HH}}=7 \mathrm{~Hz}, 8 \mathrm{H}\right.$, aryl $\left.\mathrm{CH}\right), 7.52-7.45(\mathrm{~m}, 12 \mathrm{H}$, aryl $\mathrm{CH}) .{ }^{13} \mathrm{C}\left\{{ }^{1} \mathrm{H}\right\}$ NMR (100.6 MHz, $\left.\mathrm{CDCl}_{3}\right): \delta 148.7,143.9,134.4,129.9,129.2,125.8,123.5 .{ }^{11} \mathrm{~B}$ NMR $(128.3$ $\left.\mathrm{MHz}, \mathrm{CDCl}_{3}\right): \delta-0.5\left(\mathrm{t},{ }^{1} J_{\mathrm{BF}}=29 \mathrm{~Hz}\right) .{ }^{19} \mathrm{~F} \mathrm{NMR}\left(376.1 \mathrm{~Hz}, \mathrm{CDCl}_{3}\right): \delta-144.1\left(\mathrm{q},{ }^{1} J_{\mathrm{FB}}=29 \mathrm{~Hz}\right)$. FT-IR (KBr): 3035 (m), 3004 (m), 1582 (m), 1487 (m), 1429 (m), 1322 (s), 1309 (s), 1260 (s), $1216(\mathrm{~m}), 1153(\mathrm{~m}), 1116(\mathrm{~s}) \mathrm{cm}^{-1}$. UV-vis (toluene): $\lambda_{\max }=521 \mathrm{~nm}\left(\varepsilon=28,800 \mathrm{M}^{-1} \mathrm{~cm}^{-1}\right)$. 
Mass Spec. (EI, +ve mode): exact mass calculated for $\left[\mathrm{C}_{32} \mathrm{H}_{24} \mathrm{~N}_{8} \mathrm{~B}_{2} \mathrm{~F}_{4}\right]^{+}$: 618.2246; exact mass found: 618.2257 ; difference: +1.78 ppm.

\section{Formazanate $\mathrm{BF}_{2}$ Dimer $m-10$}

From $1.91 \mathrm{mmol}$ of formazan $\boldsymbol{m - 8}$ : Yield $=0.88 \mathrm{~g}, 75 \%$. Melting point $=208-210{ }^{\circ} \mathrm{C} .{ }^{1} \mathrm{H}$ NMR $\left(599.5 \mathrm{MHz}, \mathrm{CDCl}_{3}\right) \delta 8.82(\mathrm{~s}, 1 \mathrm{H}, \operatorname{aryl} \mathrm{CH}), 8.20\left(\mathrm{~d},{ }^{3} J_{\mathrm{HH}}=8 \mathrm{~Hz}, 2 \mathrm{H}, \operatorname{aryl~CH}\right), 7.94\left(\mathrm{~d},{ }^{3} J_{\mathrm{HH}}=\right.$

$8 \mathrm{~Hz}, 8 \mathrm{H}$, aryl $\mathrm{CH}), 7.60\left(\mathrm{t},{ }^{3} \mathrm{~J}_{\mathrm{HH}}=8 \mathrm{~Hz}, 1 \mathrm{H}\right.$, aryl $\left.\mathrm{CH}\right), 7.50-7.43(\mathrm{~m}, 12 \mathrm{H}, \operatorname{aryl} \mathrm{CH}) .{ }^{13} \mathrm{C}\left\{{ }^{1} \mathrm{H}\right\}$ NMR $\left(100.6 \mathrm{MHz}, \mathrm{CDCl}_{3}\right): \delta 144.0,134.5,130.0,129.4,129.3,129.2,126.3,123.6,122.8 .{ }^{11} \mathrm{~B}$ $\operatorname{NMR}\left(128.3 \mathrm{MHz}, \mathrm{CDCl}_{3}\right): \delta-0.5\left(\mathrm{t},{ }^{1} J_{\mathrm{BF}}=29 \mathrm{~Hz}\right) .{ }^{19} \mathrm{~F} \mathrm{NMR}\left(376.1 \mathrm{~Hz}, \mathrm{CDCl}_{3}\right): \delta-143.8(\mathrm{q}$, $\left.{ }^{1} J_{\mathrm{FB}}=29 \mathrm{~Hz}\right)$. FT-IR (KBr): $3034(\mathrm{~m}), 3007(\mathrm{w}), 1581(\mathrm{~m}), 1457(\mathrm{~m}), 1454(\mathrm{~m}), 1341(\mathrm{~m}), 1301$ $(\mathrm{s}), 1281(\mathrm{~s}), 1216(\mathrm{~m}), 1179(\mathrm{~m}), 1106(\mathrm{~s}) \mathrm{cm}^{-1}$. UV-vis (toluene): $\lambda_{\max }=518 \mathrm{~nm}(\varepsilon=20,200$ $\mathrm{M}^{-1} \mathrm{~cm}^{-1}$ ). Mass Spec. (EI, +ve mode): exact mass calculated for $\left[\mathrm{C}_{32} \mathrm{H}_{24} \mathrm{~N}_{8} \mathrm{~B}_{2} \mathrm{~F}_{4}\right]^{+}: 618.2246$; exact mass found: 618.2228 ; difference: $-2.88 \mathrm{ppm}$.

\section{References}

1. Selected Reviews: a) A. Loudet and K. Burgess, Chem. Rev., 2007, 107, 4891-4932; b) G. Ulrich, R. Ziessel and A. Harriman, Angew. Chem. Int. Ed., 2008, 47, 1184-1201; c) N. Boens, V. Leen and W. Dehaen, Chem. Soc. Rev., 2012, 41, 1130-1172; d) D. Frath, J. Massue, G. Ulrich and R. Ziessel, Angew. Chem. Int. Ed., 2014, 53, 2290-2310.

2. Selected Examples: a) B. J. Liddle, R. M. Silva, T. J. Morin, F. P. Macedo, R. Shukla, S. V. Lindeman and J. R. Gardinier, J. Org. Chem., 2007, 72, 5637-5646; b) K. Umezawa, A. Matsui, Y. Nakamura, D. Citterio and K. Suzuki, Chem. Eur. J., 2009, 15, 1096-1106; c) Y. Kubota, T. Tsuzuki, K. Funabiki, M. Ebihara and M. Matsui, Org. Lett., 2010, 12, 4010-4013; d) J. F. Araneda, W. E. Piers, B. Heyne, M. Parvez and R. McDonald, 
Angew. Chem. Int. Ed., 2011, 50, 12214-12217; e) J.-s. Lu, S.-B. Ko, N. R. Walters and S. Wang, Org. Lett., 2012, 14, 5660-5663; f) Y. Kubota, Y. Ozaki, K. Funabiki and M. Matsui, J. Org. Chem., 2013, 78, 7058-7067; g) G. Nawn, S. R. Oakley, M. B. Majewski, R. McDonald, B. O. Patrick and R. G. Hicks, Chem. Sci., 2013, 4, 612-621; h) S. M. Barbon, V. N. Staroverov, P. D. Boyle and J. B. Gilroy, Dalton Trans., 2014, 43, 240250; i) A. Díaz-Moscoso, E. Emond, D. L. Hughes, G. J. Tizzard, S. J. Coles and A. N. Cammidge, J. Org. Chem., 2014, 79, 8932-8936.

3. Selected Reviews: a) M. Wainwright, Color. Technol., 2010, 126, 115-126; b) V. J. Pansare, S. Hejazi, W. J. Faenza and R. K. Prud'homme, Chem. Mater., 2012, 24, 812827; c) Y.-Q. Sun, J. Liu, X. Lv, Y. Liu, Y. Zhao and W. Guo, Angew. Chem. Int. Ed., 2012, 51, 7634-7636.

4. Selected Examples: a) E. R. Trivedi, A. S. Harney, M. B. Olive, I. Podgorski, K. Moin, B. F. Sloane, A. G. M. Barrett, T. J. Meade and B. M. Hoffman, PNAS, 2010, 107, 12841288; b) G. Hong, J. C. Lee, J. T. Robinson, U. Raaz, L. Xie, N. F. Huang, J. P. Cooke and H. Dai, Nat. Med., 2012, 18, 1841-1846; c) A. Yuan, J. Wu, X. Tang, L. Zhao, F. Xu and Y. Hu, J. Pharm. Sci., 2013, 102, 6-28; d) Y. Li, Y. Sun, J. Li, Q. Su, W. Yuan, Y. Dai, C. Han, Q. Wang, W. Feng and F. Li, J. Am. Chem. Soc., 2015, 137, 6407-6416.

5. Selected Examples: a) G. Qian, Z. Zhong, M. Luo, D. Yu, Z. Zhang, Z. Y. Wang and D. Ma, Adv. Mater., 2009, 21, 111-116; b) J. R. Sommer, R. T. Farley, K. R. Graham, Y. Yang, J. R. Reynolds, J. Xue and K. S. Schanze, ACS Appl. Mater. Interfaces, 2009, 1, 274-278; c) L. Yao, S. Zhang, R. Wang, W. Li, F. Shen, B. Yang and Y. Ma, Angew. Chem. Int. Ed., 2014, 53, 2119-2123; d) X. Cao, J. Miao, M. Zhu, C. Zhong, C. Yang, H. Wu, J. Qin and Y. Cao, Chem. Mater., 2015, 27, 96-104. 
6. Selected Examples: a) P.-A. Bouit, D. Rauh, S. Neugebauer, J. L. Delgado, E. D. Piazza, S. Rigaut, O. Maury, C. Andraud, V. Dyakonov and N. Martin, Org. Lett., 2009, 11, 4806-4809; b) M. Koppe, H.-J. Egelhaaf, G. Dennler, M. C. Scharber, C. J. Brabec, P. Schilinsky and C. N. Hoth, Adv. Funct. Mater., 2010, 20, 338-346; c) Y. Hao, X. Yang, M. Zhou, J. Cong, X. Wang, A. Hagfeldt and L. Sun, ChemSusChem, 2011, 4, 16011605; d) F. M. Jradi, X. Kang, D. O’Neil, G. Pajares, Y. A. Getmanenko, P. Szymanski, T. C. Parker, M. A. El-Sayed and S. R. Marder, Chem. Mater., 2015, 27, 2480-2487.

7. Selected Examples: a) A. C. Benniston, G. Copley, A. Harriman, D. Howgego, R. W. Harrington and W. Clegg, J. Org. Chem., 2010, 75, 2018-2027; b) S. Rihn, M. Erdem, A. De Nicola, P. Retailleau and R. Ziessel, Org. Lett., 2011, 13, 1916-1919; c) Y. Hayashi, S. Yamaguchi, W. Y. Cha, D. Kim and H. Shinokubo, Org. Lett., 2011, 13, 2992-2995; d) L. Gai, H. Lu, B. Zou, G. Lai, Z. Shen and Z. Li, RSC Adv. , 2012, 2, 8840-8846; e) A. Poirel, A. De Nicola, P. Retailleau and R. Ziessel, J. Org. Chem., 2012, 77, 7512-7525; f) A. M. Albrett, K. E. Thomas, S. Maslek, A. Młodzianowska, J. Conradie, C. M. Beavers, A. Ghosh and P. J. Brothers, Inorg. Chem., 2014, 53, 5486-5493; g) H. Yokoi, S. Hiroto and H. Shinokubo, Org. Lett., 2014, 16, 3004-3007; h) S. T. Manjare, S. Kim, W. D. Heo and D. G. Churchill, Org. Lett., 2014, 16, 410-412; i) C. Glotzbach, N. Gödeke, R. Fröhlich, C.-G. Daniliuc, S. Saito, S. Yamaguchi and E.-U. Würthwein, Dalton Trans., 2015, 44, 9659-9671.

8. a) I. J. Arroyo, R. Hu, G. Merino, B. Z. Tang and E. Peña-Cabrera, J. Org. Chem., 2009, 74, 5719-5722; b) A. Schmitt, B. Hinkeldey, M. Wild and G. Jung, J. Fluoresc., 2009, $19,755-758$. 
9. I.-S. Tamgho, A. Hasheminasab, J. T. Engle, V. N. Nemykin and C. J. Ziegler, J. Am. Chem. Soc., 2014, 136, 5623-5626.

10. a) C. Yu, L. Jiao, P. Zhang, Z. Feng, C. Cheng, Y. Wei, X. Mu and E. Hao, Org. Lett,, 2014, 16, 3048-3051; b) Q. Huaulmé, A. Mirloup, P. Retailleau and R. Ziessel, Org. Lett., 2015, 17, 2246-2249; c) L. Wang, I.-S. Tamgho, L. A. Crandall, J. J. Rack and C. J. Ziegler, Phys. Chem. Chem. Phys., 2015, 17, 2349-2351; d) X.-D. Jiang, Y. Su, S. Yue, C. Li, H. Yu, H. Zhang, C.-L. Sun and L.-J. Xiao, RSC Adv., 2015, 5, 16735-16739.

11. A. Wakamiya, T. Murakami and S. Yamaguchi, Chem. Sci., 2013, 4, 1002-1007.

12. G. M. Fischer, M. Isomäki-Krondahl, I. Göttker-Schnetmann, E. Daltrozzo and A. Zumbusch, Chem. Eur. J., 2009, 15, 4857-4864.

13. M. Nakamura, H. Tahara, K. Takahashi, T. Nagata, H. Uoyama, D. Kuzuhara, S. Mori, T. Okujima, H. Yamada and H. Uno, Org. Biomol. Chem., 2012, 10, 6840-6849.

14. a) W. Qin, M. Baruah, M. Van der Auweraer, F. C. De Schryver and N. Boens, J. Phys. Chem. A, 2005, 109, 7371-7384; b) M. T. Whited, N. M. Patel, S. T. Roberts, K. Allen, P. I. Djurovich, S. E. Bradforth and M. E. Thompson, Chem. Commun., 2012, 48, 284 286.

15. Selected Examples: a) J. B. Gilroy, B. O. Patrick, R. McDonald and R. G. Hicks, Inorg. Chem., 2008, 47, 1287-1294; b) J. B. Gilroy, M. J. Ferguson, R. McDonald and R. G. Hicks, Inorg. Chim. Acta, 2008, 361, 3388-3393; c) S. Hong, A. K. Gupta and W. B. Tolman, Inorg. Chem., 2009, 48, 6323-6325; d) A. V. Zaidman, I. G. Pervova, A. I. Vilms, G. P. Belov, R. R. Kayumov, P. A. Slepukhin and I. N. Lipunov, Inorg. Chim. Acta, 2011, 367, 29-34; e) M.-C. Chang, T. Dann, D. P. Day, M. Lutz, G. G. Wildgoose and E. Otten, Angew. Chem. Intl. Ed., 2014, 53, 4118-4122; f) M.-C. Chang and E. 
Otten, Chem. Commun., 2014, 50, 7431-7433; g) R. Travieso-Puente, M.-C. Chang and E. Otten, Dalton Trans., 2014, 43, 18035-18041; h) M.-C. Chang, P. Roewen, R. Travieso-Puente, M. Lutz and E. Otten, Inorg. Chem., 2015, 54, 379-388.

16. a) S. M. Barbon, P. A. Reinkeluers, J. T. Price, V. N. Staroverov and J. B. Gilroy, Chem. Eur. J., 2014, 20, 11340-11344; b) S. M. Barbon, J. T. Price, P. A. Reinkeluers and J. B. Gilroy, Inorg. Chem., 2014, 53, 10585-10593; c) S. M. Barbon, V. N. Staroverov and J. B. Gilroy, J. Org. Chem., 2015, 80, 5226-5235.

17. M. Hesari, S. M. Barbon, V. N. Staroverov, Z. Ding and J. B. Gilroy, Chem. Commun., 2015, 51, 3766-3769.

18. R. Kuhn, F. A. Neugebauer and H. Trischmann, Monatsh. Chem., 1966, 97, 525-553.

19. CRC Handbook of Chemistry and Physics, CRC Press, Boca Raton, FL, 2012.

20. Comproportionation would result in an increase in concentration of the bis-radical anion form of the dimers in the vicinity of the working electrode. This increase in concentration would, in turn, result in the enhancement of the anodic peak current.

21. J. B. Gilroy, S. D. J. McKinnon, P. Kennepohl, M. S. Zsombor, M. J. Ferguson, L. K. Thompson and R. G. Hicks, J. Org. Chem., 2007, 72, 8062-8069.

22. a) S. Fery-Forgues and D. Lavabre, J. Chem. Educ., 1999, 76, 1260-1264; b) K. Suzuki, A. Kobayashi, S. Kaneko, K. Takehira, T. Yoshihara, H. Ishida, Y. Shiina, S. Oishi and S. Tobita, Phys. Chem. Chem. Phys., 2009, 11, 9850-9860.

23. Bruker-AXS, SAINT version 2013.8, 2013, Bruker-AXS, Madison, WI 53711, USA.

24. Bruker-AXS, SADABS version 2012.1, 2012, Bruker-AXS, Madison, WI 53711, USA.

25. G. M. Sheldrick, Acta Cryst., 2015, A71, 3-8.

26. G. M. Sheldrick, Acta Cryst., 2008, A64, 112-122. 


\title{
Supplementary Information
}

\section{Synthesis and Characterization of Conjugated/Cross- \\ Conjugated Benzene-Bridged Boron Difluoride}

\author{
Formazanate Dimers
}

Stephanie M. Barbon, Jacquelyn T. Price, Umesh Yogarajah and Joe B. Gilroy*

Department of Chemistry and the Centre for Advanced Materials and Biomaterials Research (CAMBR), The University of Western Ontario, 1151 Richmond St. N., London, Ontario, Canada, N6A 5B7. Tel: +1-519-661-2111 ext. 81561; E-mail: joe.gilroy@uwo.ca

\section{Table of Contents}

${ }^{1} \mathrm{H}$ and ${ }^{13} \mathrm{C}$ NMR for formazans $\boldsymbol{m - 8}$ and $\boldsymbol{p}$-8 and ${ }^{13} \mathrm{C}$ NMR for dimers $\boldsymbol{m}$-10 and $\boldsymbol{p}$-10 $\mathrm{S} 2$

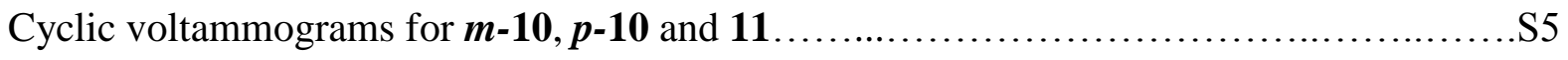

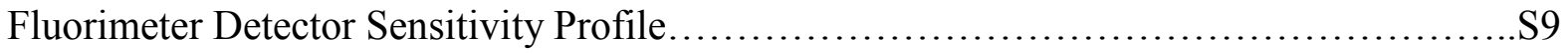




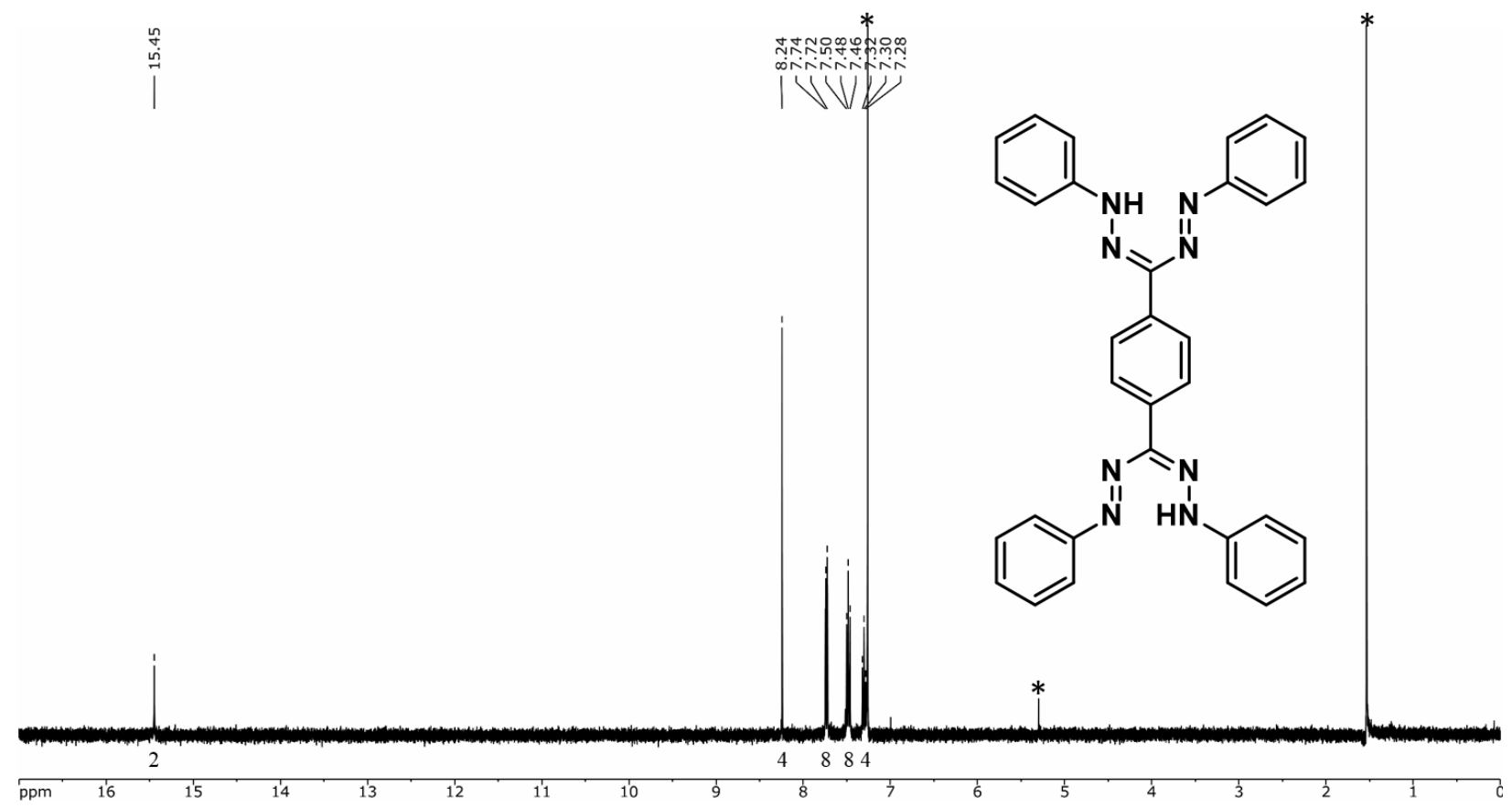

Figure S1. ${ }^{1} \mathrm{H}$ NMR spectrum of $\boldsymbol{p - 8}$ in $\mathrm{CDCl}_{3}$. The asterisks denote residual solvent signals.

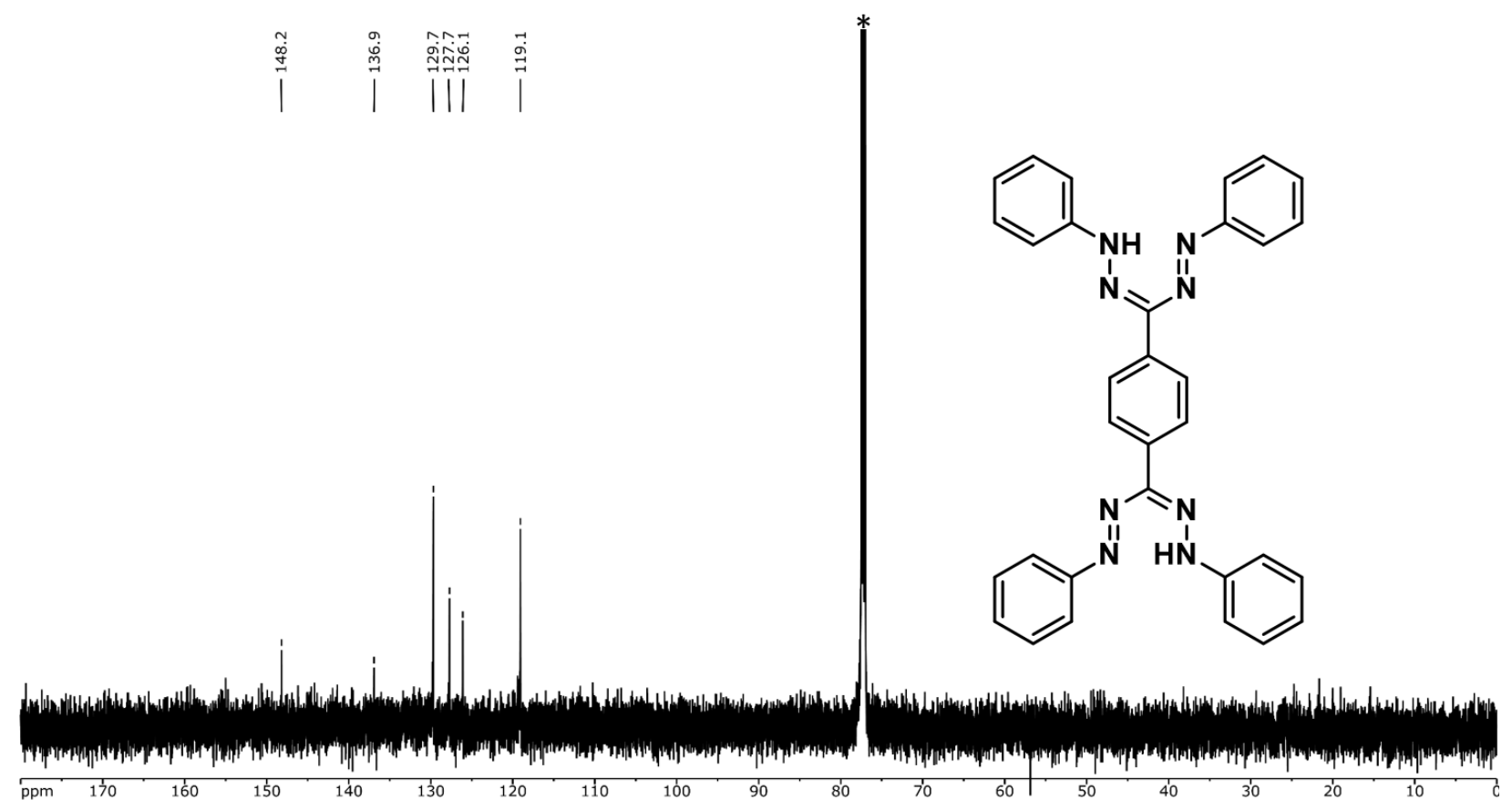

Figure S2. ${ }^{13} \mathrm{C}\left\{{ }^{1} \mathrm{H}\right\}$ NMR spectrum of $\boldsymbol{p - 8}$ in $\mathrm{CDCl}_{3}$. The asterisk denotes solvent signal. This spectrum was collected for 10,000 scans on a $600 \mathrm{MHz}$ spectrometer. The poor signal-to-noise ratio relates to the poor solubility of $\boldsymbol{p - 8}$. 


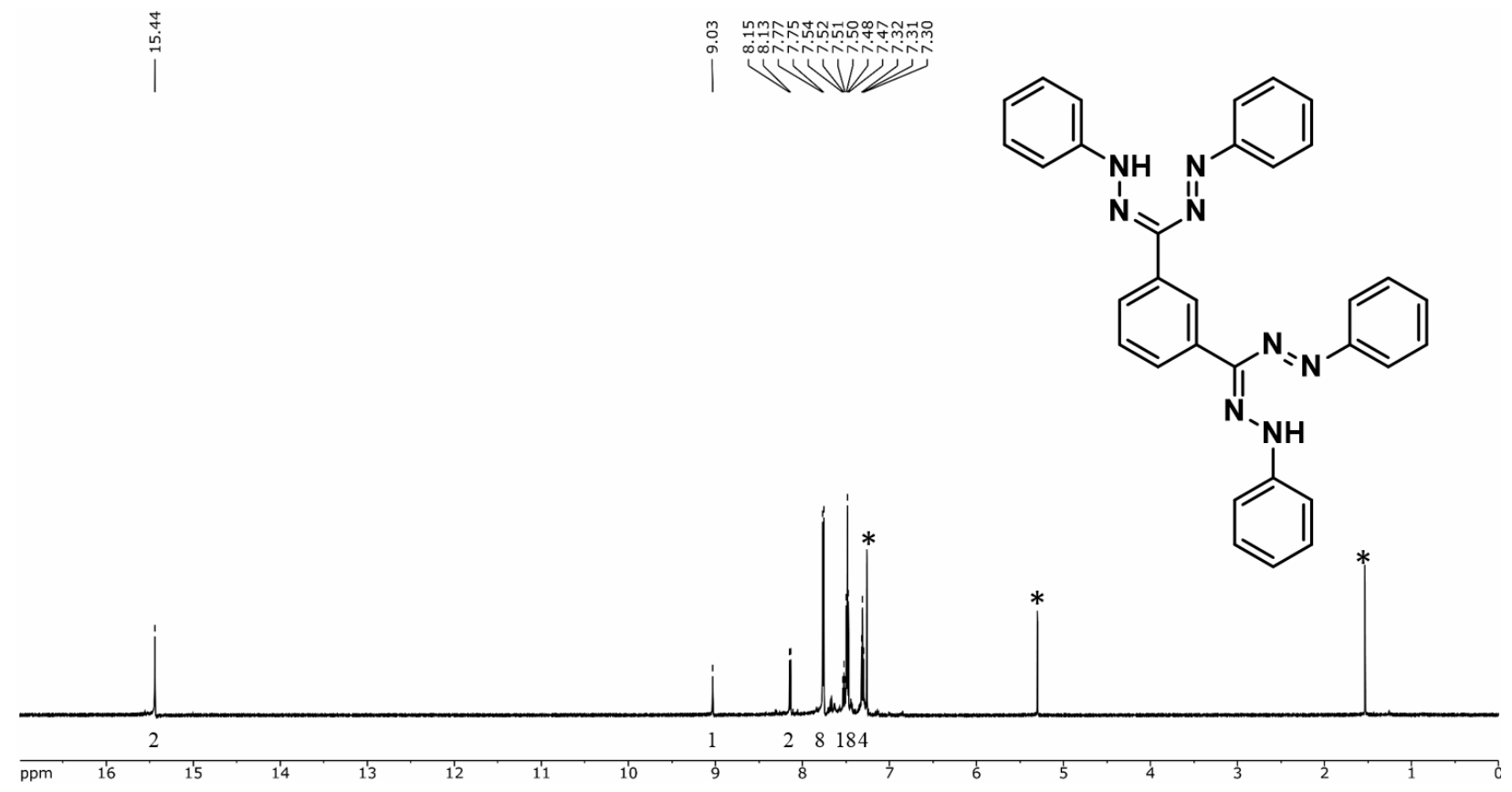

Figure S3. ${ }^{1} \mathrm{H}$ NMR spectrum of $\boldsymbol{m - 8}$ in $\mathrm{CDCl}_{3}$. The asterisks denote residual solvent signals.

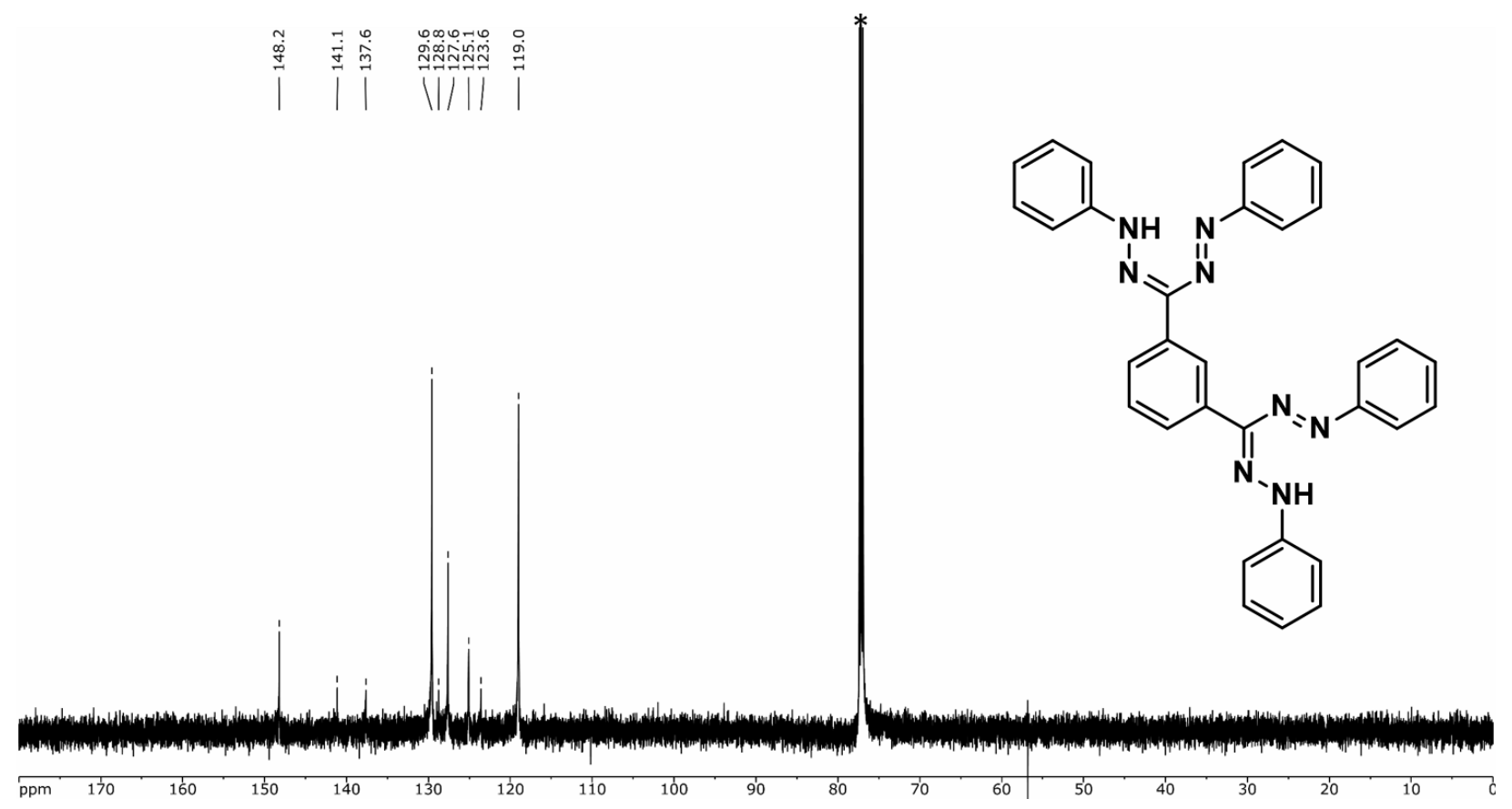

Figure S4. ${ }^{13} \mathrm{C}\left\{{ }^{1} \mathrm{H}\right\}$ NMR spectrum of $\mathbf{m - 8}$ in $\mathrm{CDCl}_{3}$. The asterisk denotes solvent signal. 


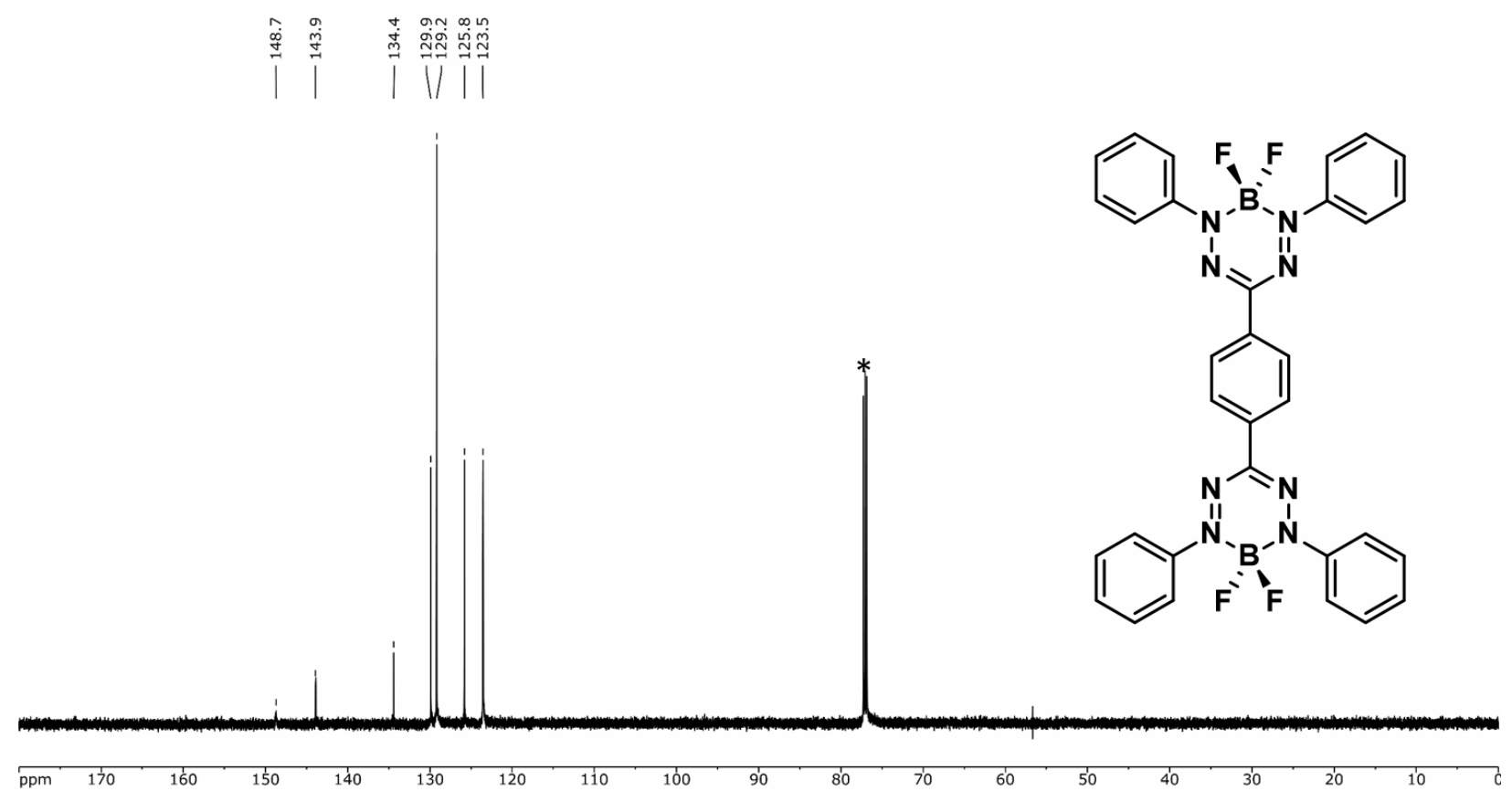

Figure S5. ${ }^{13} \mathrm{C}\left\{{ }^{1} \mathrm{H}\right\}$ NMR spectrum of $\boldsymbol{p}-\mathbf{1 0}$ in $\mathrm{CDCl}_{3}$. The asterisk denotes solvent signal.

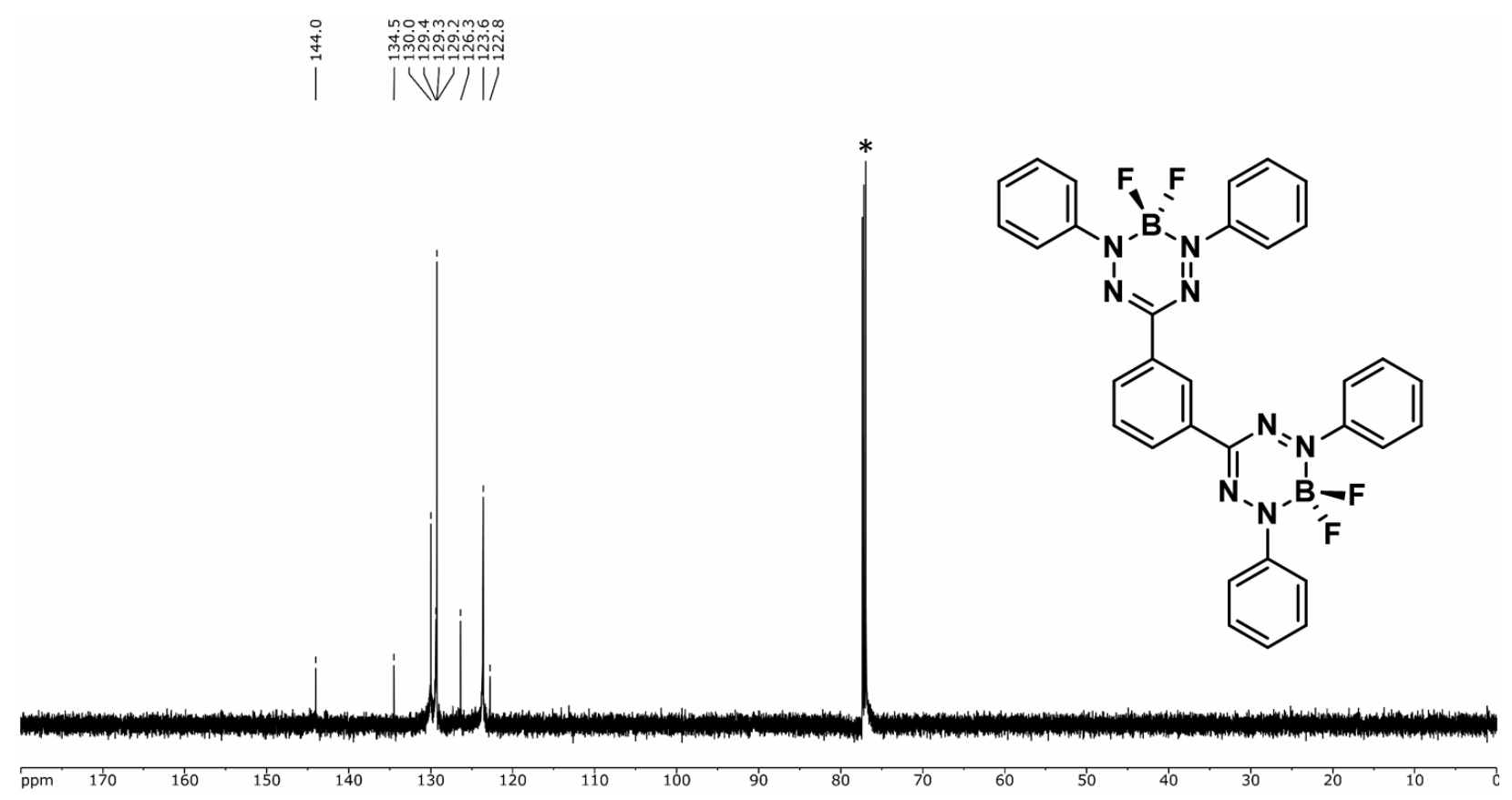

Figure S6. ${ }^{13} \mathrm{C}\left\{{ }^{1} \mathrm{H}\right\}$ NMR spectrum of $\boldsymbol{m - 1 0}$ in $\mathrm{CDCl}_{3}$. The asterisk denotes solvent signal. 


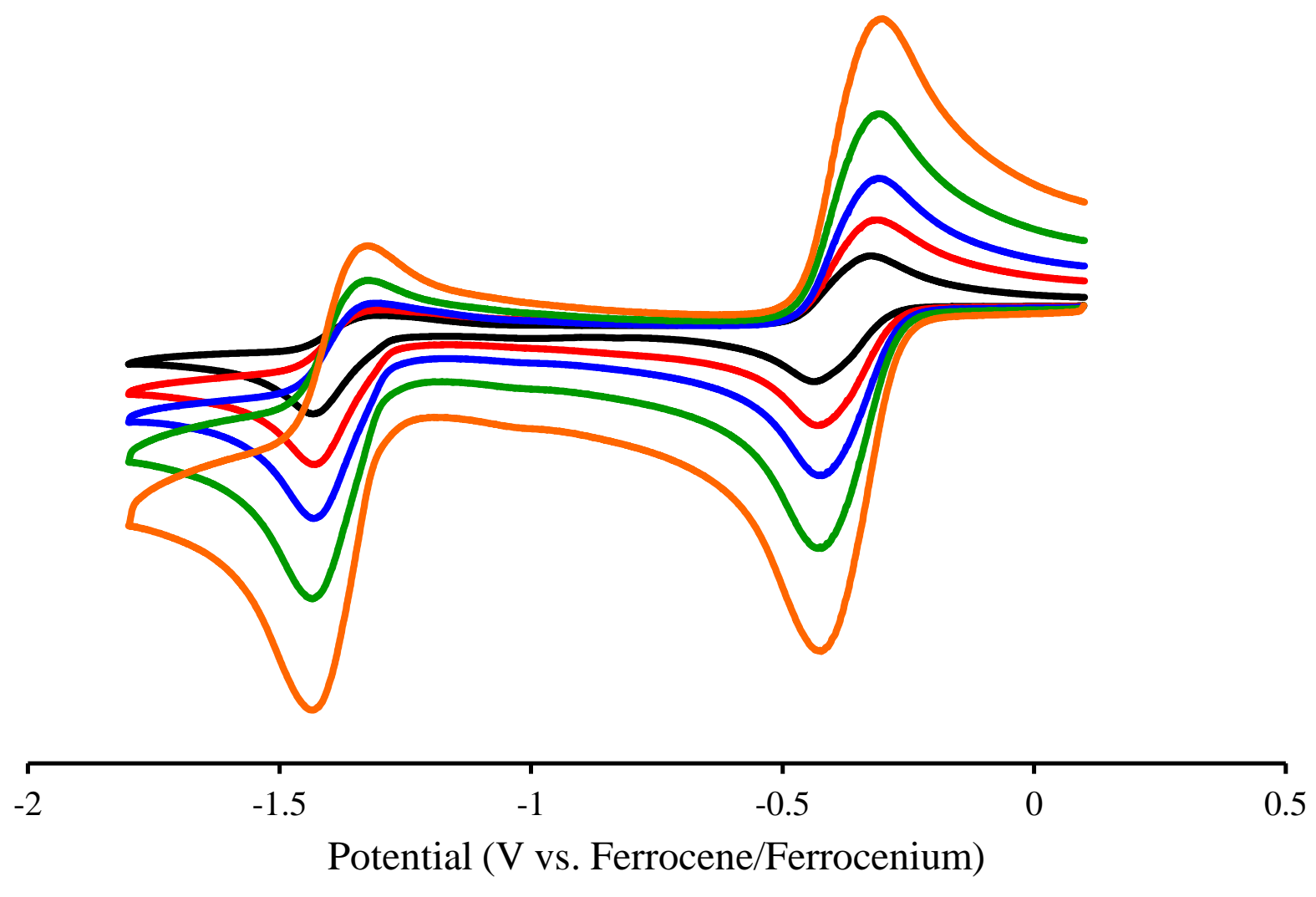

Figure S7. Scan rate dependence of $\boldsymbol{p - 1 0}$ in $1 \mathrm{mM}$ dichloromethane solution containing $0.1 \mathrm{M}$ tetrabutylammonium hexafluorophosphate as supporting electrolyte run at $100 \mathrm{mV} \mathrm{s}^{-1}$ (black), $250 \mathrm{mV} \mathrm{s}^{-1}$ (red), $500 \mathrm{mV} \mathrm{s}^{-1}$ (blue), $1000 \mathrm{mV} \mathrm{s}^{-1}$ (green) and $2000 \mathrm{mV} \mathrm{s}^{-1}$ (orange). 


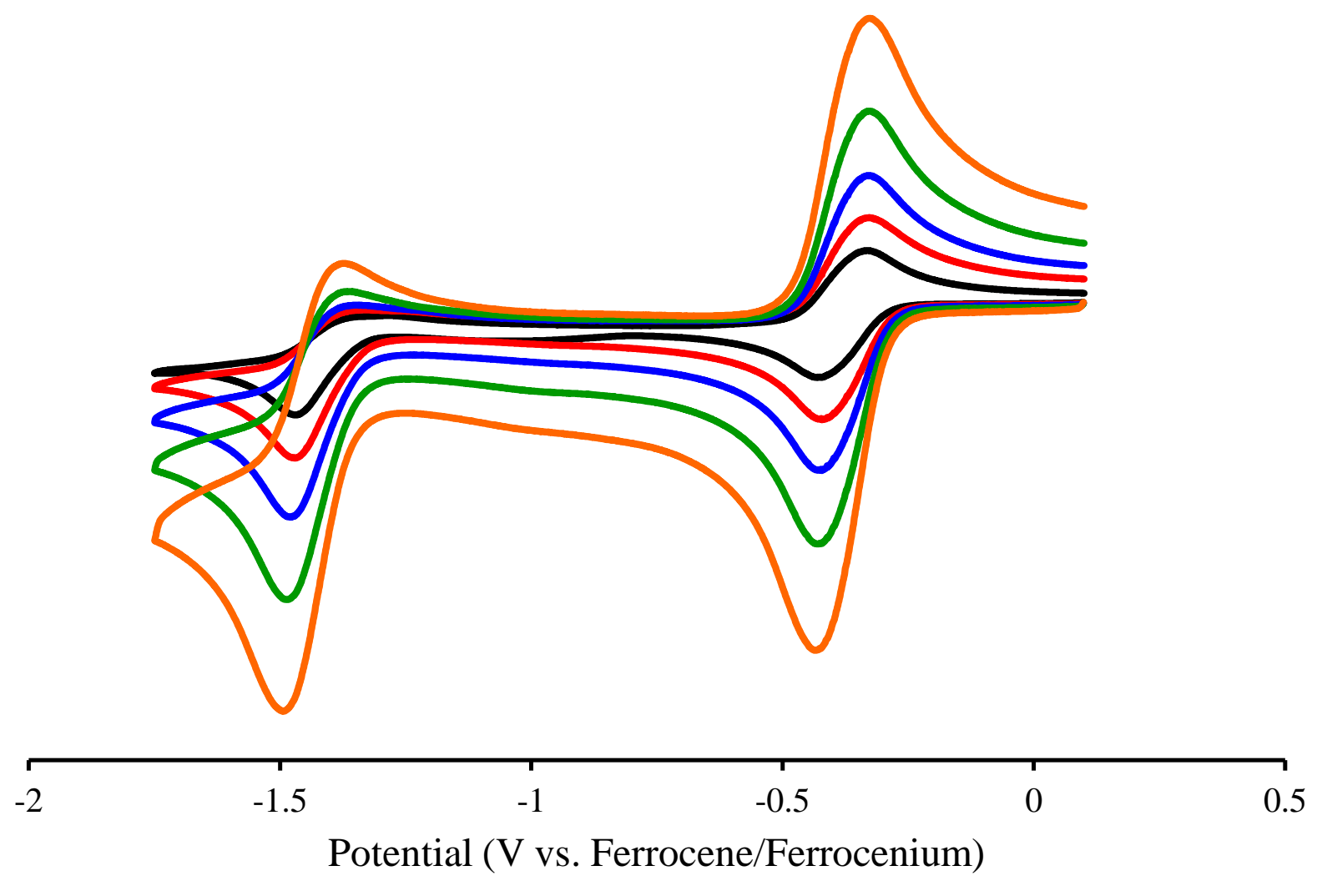

Figure S8. Scan rate dependence of $\boldsymbol{m - 1 0}$ in $1 \mathrm{mM}$ dichloromethane solution containing $0.1 \mathrm{M}$ tetrabutylammonium hexafluorophosphate as supporting electrolyte run at $100 \mathrm{mV} \mathrm{s} \mathrm{s}^{-1}$ (black), $250 \mathrm{mV} \mathrm{s}^{-1}$ (red), $500 \mathrm{mV} \mathrm{s}^{-1}$ (blue), $1000 \mathrm{mV} \mathrm{s}^{-1}$ (green) and $2000 \mathrm{mV} \mathrm{s}^{-1}$ (orange). 

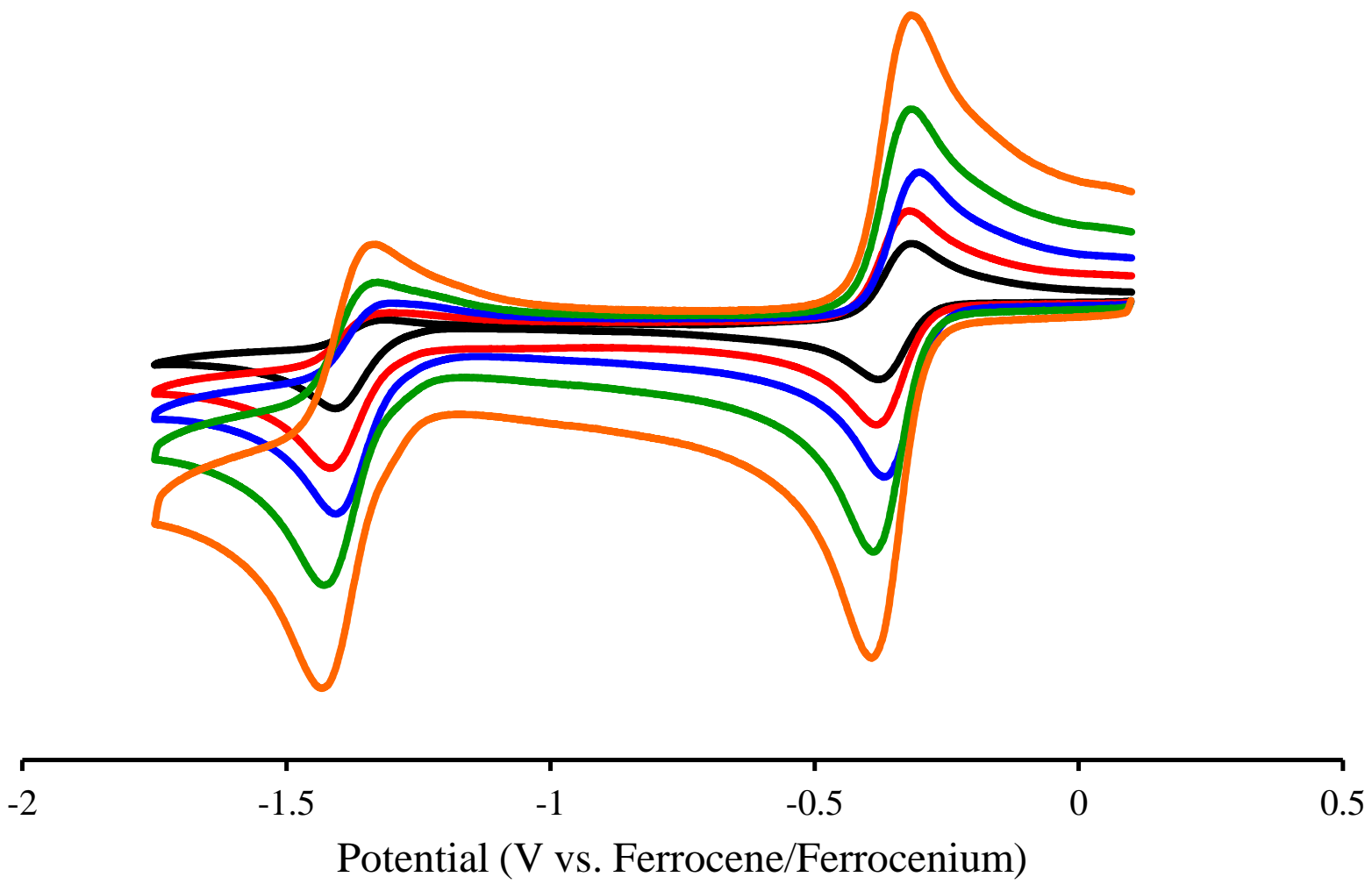

Figure S9. Scan rate dependence of $\mathbf{1 1}$ in $1 \mathrm{mM}$ dichloromethane solution containing $0.1 \mathrm{M}$ tetrabutylammonium hexafluorophosphate as supporting electrolyte run at $100 \mathrm{mV} \mathrm{s}^{-1}$ (black), $250 \mathrm{mV} \mathrm{s}^{-1}$ (red), $500 \mathrm{mV} \mathrm{s}^{-1}$ (blue), $1000 \mathrm{mV} \mathrm{s}^{-1}$ (green) and $2000 \mathrm{mV} \mathrm{s}^{-1}$ (orange). 


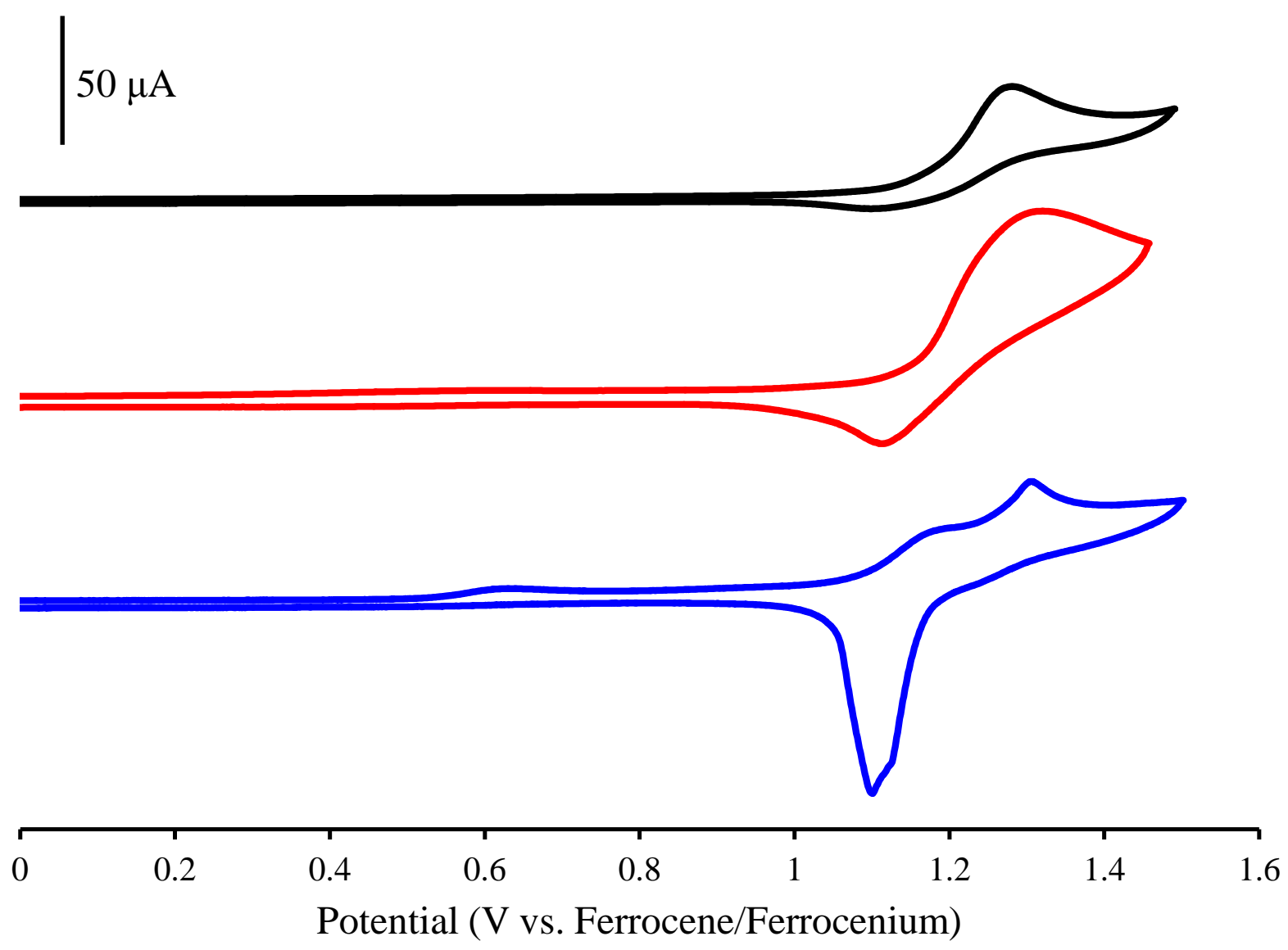

Figure S10. Cyclic voltammograms of $\boldsymbol{p}$-10 (blue), $\boldsymbol{m - 1 0}$ (red) and $\mathbf{1 1}$ (black) recorded at $100 \mathrm{mV} \mathrm{s}^{-1}$ in $1 \mathrm{mM}$ dichloromethane solutions containing $0.1 \mathrm{M}$ tetrabutylammonium hexafluorophosphate as supporting electrolyte. 


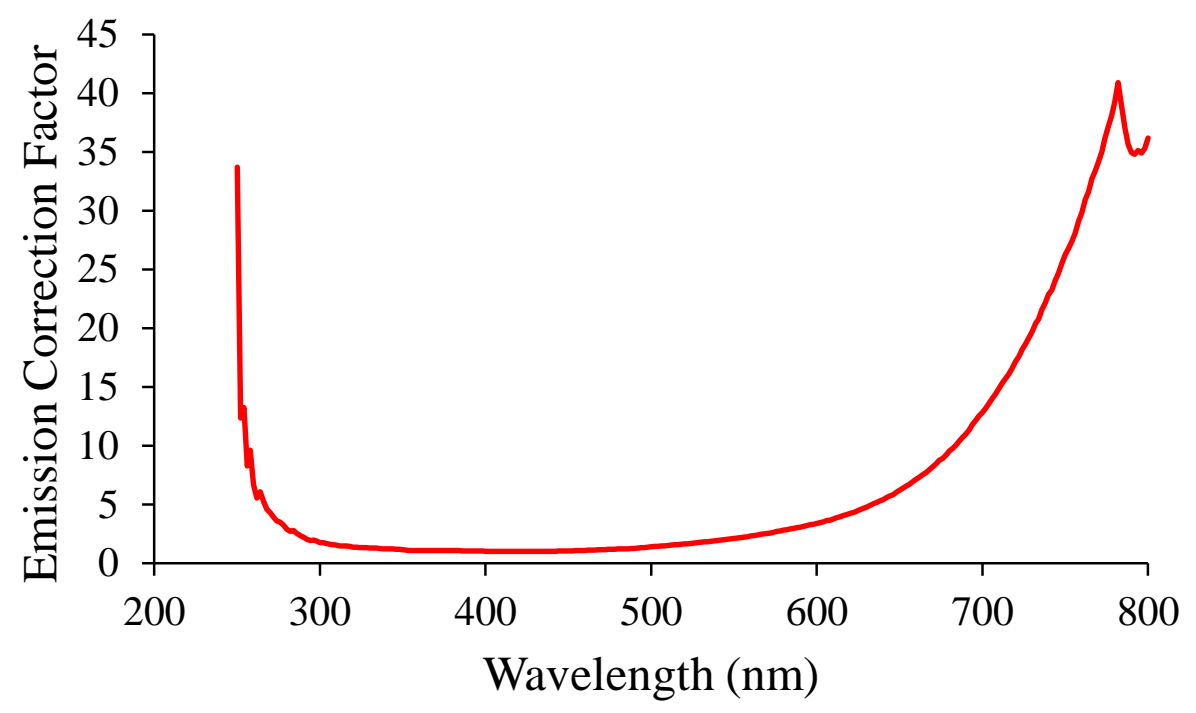

Figure S11. Wavelength-dependent emission correction provided by Photon Technology International. 